\title{
Biosensors for environmental applications: Future development trends*
}

\author{
Sara Rodriguez-Mozaz ${ }^{1}$, Maria-Pilar Marco², Maria J. Lopez de Alda', \\ and Damià Barceló ${ }^{1, \ddagger}$
}

\author{
${ }^{1}$ Department of Environmental Chemistry, IIQAB-CSIC, C/Jordi Girona 18-26, \\ 08034 Barcelona, Spain; ${ }^{2}$ Department of Biological Organic Chemistry, \\ IIQAB-CSIC, C/Jordi Girona 18-26, 08034 Barcelona, Spain
}

\begin{abstract}
Biosensors can be excellent analytical tools for monitoring programs working to implement legislation. In this article, biosensors for environmental analysis and monitoring are extensively reviewed. Examples of biosensors for the most important families of environmental pollutants, including some commercial devices, are presented. Finally, future trends in biosensor development are discussed. In this context, bioelectronics, nanotechnology, miniaturization, and especially biotechnology seem to be growing areas that will have a marked influence on the development of new biosensing strategies in the next future.
\end{abstract}

\section{INTRODUCTION}

Public concern and legislation are nowadays demanding better environmental control. In addition, the increase in the number of analytes to monitor requires more suitable analytical methods. For conventional "off-site" analysis, samples need to be sent to a laboratory for testing. Conventional methods are actually reaching the highest accuracy with low detection limits, but are expensive, time-consuming, and require the use of highly trained personnel [1]. The current tendency to carry out field monitoring has driven the development of biosensors as new analytical tools able to provide fast, reliable, and sensitive measurements with lower cost; many of them aimed at on-site analysis. In this sense, biosensors would not compete with official analytical methods, but they can be used both by regulatory authorities and by industry to provide enough information for routine testing and screening of samples [2]. Biosensors are defined as analytical devices incorporating a biological material, a biologically derived material, or biomimic, intimately associated with or integrated within a physicochemical transducer or transducing microsystem [3]. Biosensors should be distinguished from a bioassay or a bioanalytical system, which require additional processing steps, such as reagent addition [4] and where the assay design is permanently fixed in the construction of the device.

Biosensors are being developed for different applications, including environmental and bioprocess control, quality control of food, agriculture, military, and, particularly, medical applications. In fact, most of the commercially available biosensor systems are applied in the clinical and pharmaceutical markets. Accordingly, most research and development has been devoted to this area. In the food industry, the detection of contaminants, verification of product content, monitoring of raw materials conversion, and product freshness [5] are areas of potential biosensor application. The beer industry has already identified ways for improving and controlling their products through the use of biosensors [6]. Biosensors can be also a defense tool through the early detection of hazardous materials such as germs

\footnotetext{
*Plenary lecture presented at the Southern and Eastern Africa Network of Analytical Chemists (SEANAC), Gaborone, Botswana, 7-10 July 2003. Other presentations are published in this issue, pp. 697-888.

${ }^{\ddagger}$ Corresponding author
} 
or chemical warfares. The detection of illicit drugs and explosives, with airport security purposes, is also a major area of research in biosensors [5]. For environmental control and monitoring, biosensors can provide fast and specific data of contaminated sites. They offer other advantages over current analytical methods such as the possibility of portability and working on-site and the ability of measuring pollutants in complex matrices with minimal sample preparation. On the other hand, biosensors offer the possibility of determining not only specific chemicals, but also their biological effects, such as toxicity or endocrine-disrupting effects, which are sample information of great interest.

\section{BIOSENSOR CONFIGURATIONS}

Biosensors are usually classified into various basic groups, according to the signal transduction and to the biorecognition principles. On the basis of the transducing element, biosensors can be categorized as electrochemical, optical, piezoelectric, and thermal sensors. The electrochemical biosensors, and among them the amperometric and the potentiometric ones, are the best described in the literature; those based on optical principles are the next most commonly used transducers. In fact, most catalytic biosensors are based on electrochemical methods, whereas affinity biosensors have generally proved more amenable to optical detection methods [7]. The various types of optical transducers exploit properties such as simple light absorption, fluorescence/phosphorescence, bio/chemiluminescence, reflectance, Raman scattering, and refractive index [5]. Surface plasmon resonance (SPR) is another common transduction mechanism whose main advantage over most optical biosensors is that the analyte presence can be determined directly, without the use of labeled molecules. Finally, cantilever biosensors are an emerging group of biosensors, which are based on the bending of silicon cantilevers caused by the adsorption of target molecules onto the cantilever surface, where receptor molecules are immobilized.

According to the biorecognition principle, biosensors are classified into immunochemical, enzymatic, nonenzymatic receptor, whole-cell, and DNA biosensors. Immunosensors present the advantages of sensitivity and selectivity inherent to the use of immunochemical interactions. Limitations are the troubles derived from the regeneration of the immunosurface, and cross-reactivity, although a certain degree of cross-reactivity is often desirable in order to determine different congeners of the same family. Enzymes are suitable to act as recognition elements because of their specificity and the wide range of enzymes available. In general, enzymatic biosensors are based on the selective inhibition of specific enzymes by different classes of compounds. The decrease of activity of the immobilized enzyme in the presence of the target analyte is frequently used for its quantification. Biosensors based on natural receptors can be built by integrating the specific receptor within a membrane and by coupling it to a transducing device. These natural receptors are proteins of noncatalytic or nonimmunogenic origin, which span cell membranes and can specifically bind certain compounds. The binding signal is detected as a structural change or an associated enzyme activity. Whole cells of living organisms, such as bacteria, yeast, fungi, plant and animal cells, or even tissue slices have been used as the recognition component by interrogating their general metabolic status. These biosensors are useful to determine whether a substance is toxic to certain cells. Another application of whole-cell biosensors is the determination of the "biological oxygen demand" (BOD). In the case of DNA biosensors, two strategies are applied to detect pollutants: one is the hybridization detection of nucleic acid sequences from infectious microorganisms, and the other one, the monitoring of small pollutants interacting with the immobilized DNA layer (drugs, mutagenic pollutants, etc.) [8].

One key step in the development of biosensors is the immobilization of the biological component at the transducer surface. The immobilization procures both the stabilization of the biomaterial and the proximity between the biomaterial and the transducer. The immobilization methods most generally employed are: physical adsorption at a solid surface, cross-linking between molecules, covalent binding to a surface, and entrapment within a membrane, surfactant matrix, polymer or microcapsule [5]. In addition to these conventional methods, sol-gel entrapment, Langmuir-Blodgett (LB) deposition, electropolymerization, self-assembled biomembranes and bulk modification have been also used. 


\section{ENVIRONMENTAL APPLICATIONS}

In the following section, we describe biosensors developed for environmental monitoring, considering first, biosensors that measure an effect such as toxicity and endocrine effect biosensors and second, biosensors that detect a compound or a group of compounds based on the specific recognition of a biomolecule. A wide range of compounds of environmental concern or under suspicion are being considered for biosensor development. Table 1 lists examples of these reported biosensors for different environmental applications.

\section{Toxicity}

In environmental pollution monitoring, it is becoming a general opinion that chemical analysis by itself does not provide sufficient information to assess the ecological risk of polluted waters and wastewaters [9]. In the European Union, along with more stringent demands for water treatment (Council Directive 91/271/EEC), industrial and urban wastewater effluents shall reach certain limits of nontoxicity before the effluent can be discharged into the environment. Thus, much effort has been made during the last years to develop and use different bioassays and biosensors for toxicity evaluation of water samples [9].

Whole organisms are used to measure the potential biological impact (toxicity) of a water or soil sample. That is the case of the toxicity assays Microtox ${ }^{\circledR}$ (Azure, Bucks, UK), or ToxAlert ${ }^{\circledR}{ }^{(M e r c k \text {, }}$ Darmstadt, Germany). These systems are based on the use of luminescent bacteria, Vibrio fischeri, to measure toxicity from environmental samples. Bacterial bioluminescence has proved to be a convenient measure of cellular metabolism and, consequently, a reliable sensor for measuring the presence of toxic chemicals in aquatic samples. Some bioassay methods are integrated now in biosensors such as the Cellsense $^{\circledR}$, which is an amperometric sensor that incorporates Escherichia coli bacterial cells for rapid ecotoxicity analysis. It uses ferricyanine, a soluble electron mediator, to divert electrons from the respiratory system of the immobilized bacteria of a suitable carbon electrode. The resulting current is, thus, a measure of bacterial respiratory activity, and the perturbation by pollutants can be detected as a change in the magnitude of the current. Cellsense has been applied to investigate the toxicity of 3,5-dichlorophenol and other phenols in wastewater [10], for the determination of nonionic surfactants and benzene sulfonate compounds [11], for the analysis of wastewater treatment works (WWTW) influent and effluent [11], and for the toxicity testing of wastewaters and sewage sludge [12]. Moreover, Cellsense has been proposed as one of the newer rapid toxicity assessment methods within the direct toxicity assessment (DTA) demonstration program of the UK Environmental Agency [13].

Most environmental biosensors have focused on bacterial systems while eukariotic biosensors are rare; even more rare is the use of mammalian cells. The mammalian cell, which is more complex than bacteria, can give a more sensitive response when compared to bacteria while also responding to the estrogenic effects of chemicals [14]. A recombinant fluorescent Chinese Hamster Ovary cell line, utilizing a fluorescent reporter system, was used to monitor various toxicants, especially endocrine-disrupting compounds (EDCs), in diverse aqueous environments [14]. EDCs have been also analyzed by Gu et al. [15] with a multichannel two-stage mini-bioreactor system using a genetically engineered bioluminescent bacteria. The toxicity of various samples spiked with known endocrine-disrupting chemicals, and phenol was investigated.

\section{Endocrine effect biosensors}

Nowadays, there is an increasing concern regarding many environmental contaminants that produce adverse effects by interfering with endogenous hormone systems, the so-called EDCs. EDCs constitute a class of substances not defined by chemical nature, but by biological effect and thus, taking advantage

(Text continues on $p .730$.) 
S. RODRIGUEZ-MOZAZ et al.

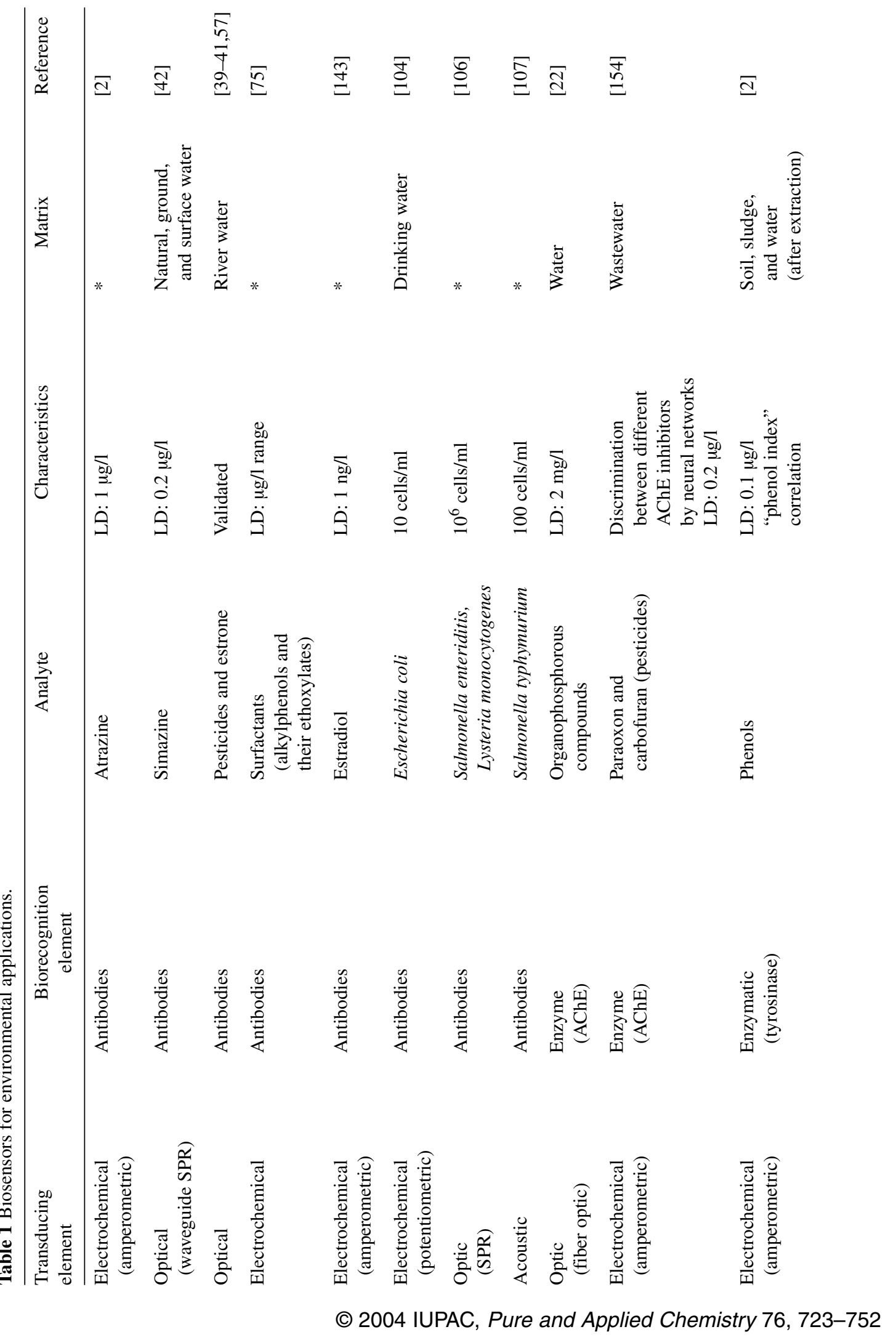




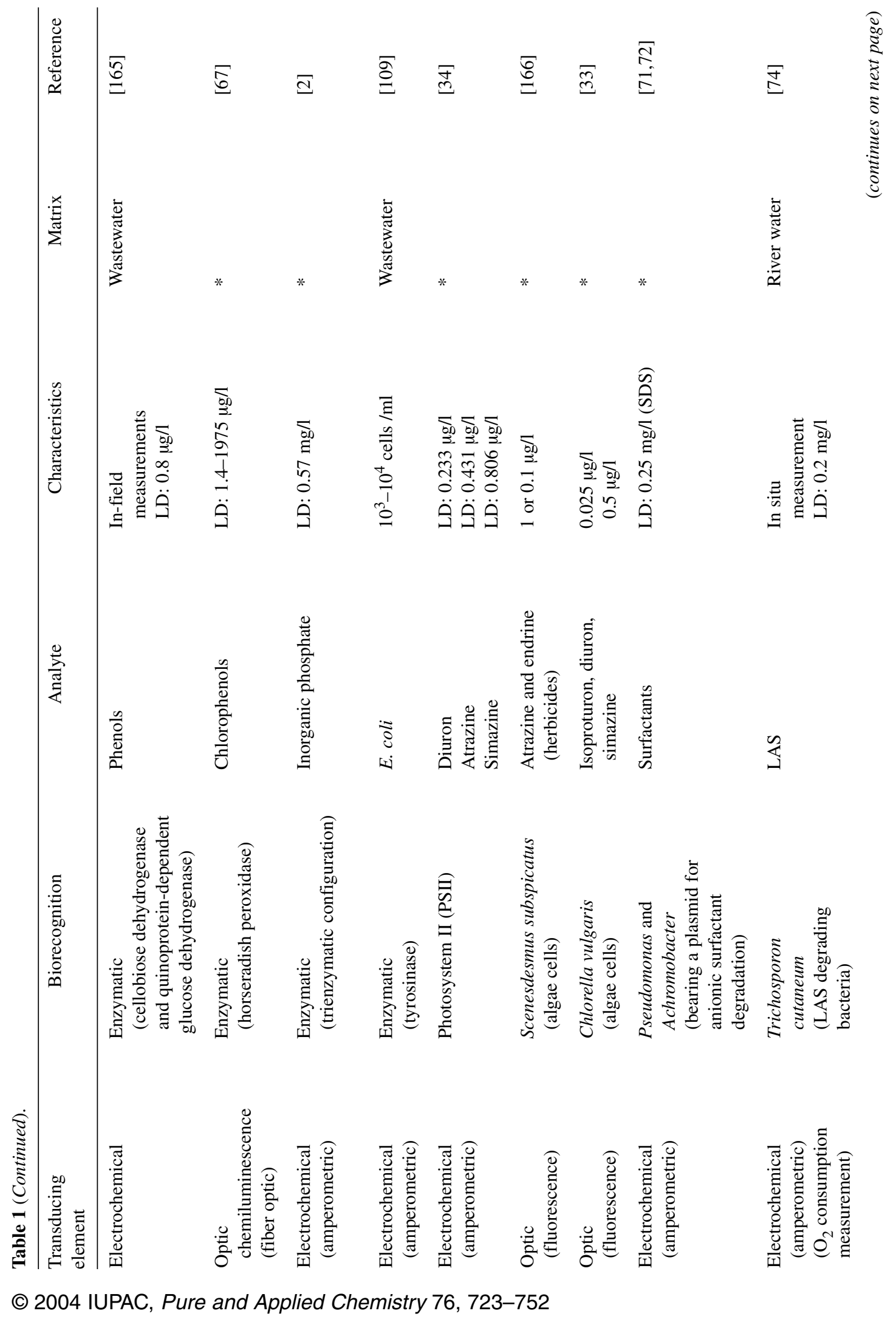


S. RODRIGUEZ-MOZAZ et al.

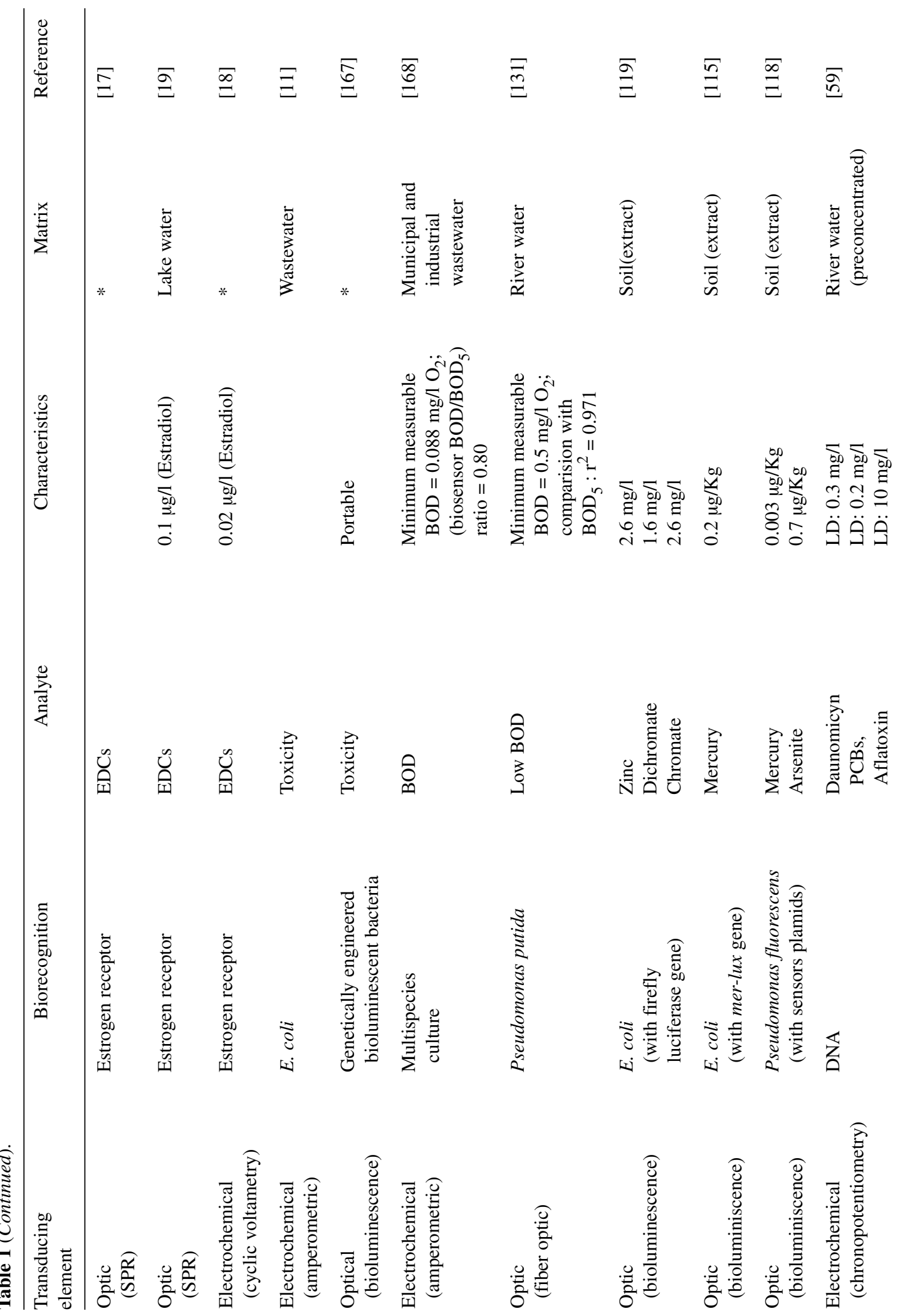

(C) 2004 IUPAC, Pure and Applied Chemistry 76, 723-752 


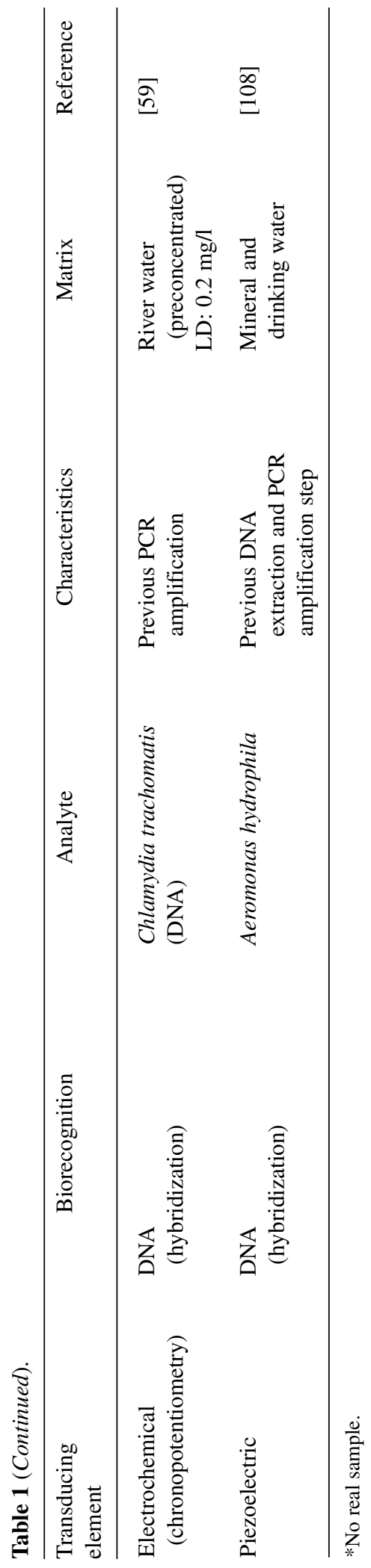

(C) 2004 IUPAC, Pure and Applied Chemistry 76, 723-752 
of this feature, "endocrine effect biosensors" have been developed. Steroid hormones induce different effects in mammalian cells after binding to specific intercellular receptors, which are ligand-dependent transcription factors. Many endocrine disruptors are also believed to bind to the estrogen receptor (ER) as agonists or antagonists. Thus, the binding ability of the chemicals toward the ER would be a crucial factor for screening or testing their potential environmental toxicity. Based on estrogen receptors, several biosensors have been developed which provide significant and useful information about estrogenic potency of the sample. The advantage of receptor assays is that they are quite simple to perform and allow the identification of all endocrine disruptors that act through the corresponding receptor [16]. These biosensors constitute a similar approach as that described above for toxicity biosensors, where effects as a general parameter and not a specific substance are monitored. By employing the commonly utilized human estrogen receptor, the SPR biosensor BIAcore has been applied in the determination of estrogens and xenoestrogens and in binding studies of target compounds [17-19]. In addition to optical biosensors, electrochemical [20] and piezoelectric [21] biosensors have been developed also based on estrogen receptors.

\section{Biocides}

The extensive use of pesticides for agricultural purposes is the cause of their widespread presence in natural waters. Concerns about their toxicity and persistence in the environment has led the European Community to set limits on the concentration of pesticides in different environmental waters: The directive 98/83/EC on the quality of water for human consumption has set a limit of $0.1 \mu \mathrm{g} / \mathrm{l}$ for individual pesticides and of $0.5 \mu \mathrm{g} / \mathrm{l}$ for total pesticides. Although conventional techniques such HPLC/MS and GC/MS gives satisfactory analytical results for pesticide determination, new assays and sensors for cheaper and faster on-site analysis are being developed. Enzymatic sensors, based on the inhibition of a selected enzyme, are the most extended biosensors used for the determination of these compounds. Based on the inhibition of acetyl cholinesterase (AChE) and colin oxidase, various biosensors have been developed for the detection of organophosphorous and carbamate pesticides such as those described by Choi et al. [22], Vangelis et al. [23], and Andres et al. [24]. Although sensitive, biosensors based on AchE inhibition are not selective (since the AchE is inhibited by neurotoxins, which include organophosphorous pesticides (OPs), carbamate pesticides, and many other compounds) and cannot, therefore, be used for quantitation of either an individual or a class of pesticides. One approach to solve the lack of specificity of AchE involves the genetic engineering of cholinesterase enzyme to obtain new specific enzymes for desired analytes or families. Different expression systems for the production of recombinant AChEs for biosensor applications were reviewed by Schulze et al. [25]. The organophosphorous hydrolase (OPH), on the other hand, is able to hydrolyze a number of OP pesticides such as paraoxon and parathion, and chemical warfare agents such as sarin and soman. Hydrolysis of these OP pesticides generates $p$-nitrophenol, which is an electroactive and chromophoric product. Thus, OPH could be combined with an optical transducer to measure the absorbance of $p$-nitrophenol or with an amperometric transducer to monitor the oxidation or reduction current of this product [26]. With a different approach, the capability of various pesticides such as cyanide [27], diethyldithiocarbamates [28], and hydrazines [29] to inhibit the enzyme tyrosinase was also reported. Similarly, diazinon and dichlorvos were detected at limits around $5 \mu \mathrm{M}$ and $75 \mu \mathrm{M}$, respectively, using a tyrosinase-based oxygen sensor [30]. Dithiocarbamate fungicides have been measured by their ability to inhibit the enzyme aldehyde dehydrogenase (AIDH). Particularly, the detectability of the pesticide Maneb could be improved to a level of $1.5 \mu \mathrm{g} / \mathrm{l}$, by using a bienzymatic system based on the combination of AlDH and diaphorase [31]. Photosynthesis inhibition is an interesting indicator that rapidly reflects the toxic effect of certain pollutants. Taking advantage of this feature, some biosensors based on Photosystem II (PSII) have been reported to be able to detect herbicides in the environment [32]. About $30 \%$ of herbicides, including phenylurea, triazine, and phenolic herbicides, inhibit photosynthetic electron flow by blocking the PSII quinone-binding site and thus modify chlorophyll fluorescence [33]. An amperometric biosensor de- 
veloped by Koblizek et al. [34] exhibited, for example, selective sensitivity to phenylurea and triazine herbicides, whereas phenolic herbicides were not registered. Heavy metals were also able to inhibit the activity of the PSII biosensor, but their effect is usually found at much higher concentrations than those typical for herbicides. Another PSII-based biosensor [33] allowed the detection of herbicides such as atrazine, simazine, isoproturon, and diuron at sub- $\mu \mathrm{g} / \mathrm{l}$ concentration levels.

In a different approach, biosensors based on immunological assays have been developed. Wilmer et al. [35], determined 2,4-dichlorophenoxyacetic (2,4-D) acid in water by an amperometric immunosensor. In this immunosensor, the enzyme alkaline phosphatase (AP) catalyzes the conversion of PAPP to PAP allowing a limit of detection of $0.1 \mu \mathrm{g} / \mathrm{l}$. Based on the evanescent wave (EW) transducing principle, atrazine was detected at concentrations around $0.1 \mu \mathrm{g} / 1[36,37]$ and cyclodiene insecticides in the $\mu \mathrm{g} / \mathrm{l}$ range [38]. Mallat et al. [39-41] applied the "River Analyzer" (RIANA) immunosensor in the determination of pesticides such as atrazine, simazine, isoproturon, 2,4-D, alachlor, and paraquat in natural waters. Studies focused on the evaluation of matrix effects, interferences due to the presence of cross-reactant substances and on the validation of the sensor. The system was used for monitoring of atrazine, simazine, and alachlor in different Spanish and Portuguese regions. Based also on SPR principle, another immunosensor was used to measure triazine pesticides [42] achieving a detection limit for simazine of $0.2 \mu \mathrm{g} / \mathrm{l}$. Analyses carried out on surface and groundwater samples showed a good correlation with parallel chromatographic results. An immunosensor for the determination of Irgarol 1051 was applied to the direct analysis of natural waters and water extracts [43]. It allowed the analysis of samples with an organic solvent content of up to 50 or $25 \%$ of methanol and acetonitrile, respectively [44]. In spite of the lack of specificity and the interferences observed in liquid media, some applications have also been reported on the use of piezoelectric immunosensors for the determination of pesticides such as atrazine [45,46], 2,4-D [47], and parathion [48]. Recently, a label-free direct piezoelectric immunosensor built on a flow-through cell was used for the determination of 2,4-D in water with a limit of detection around $0.2 \mu \mathrm{g} / \mathrm{l}[49]$.

\section{Hormones}

Endogenous hormones of human or animal origin have been reaching the environment for thousands of years, even though to an increasing extent they are due to growing population and more intensive farming. Besides endogenous hormones, exogenous sex steroids used as growth promoters in several countries have become a matter of concern not only because of the residues potentially found in meat, but also because environmental soil and water samples may be contaminated as result of the animal excreta. These residues may have endocrine-disrupting activity in aquatic fauna or even terrestrial [50]. Although very low concentrations (ng/l range) of hormones such as estradiol, estrone, and ethynilestradiol have been found in water [51-54], their widespread use and their capability to induce responses in fish at concentrations as low as ng/l or even $\mathrm{pg} / \mathrm{l}$ level, have alerted scientists to the potential dangerous consequences of their presence in the aquatic environment $[55,56]$. As an example, estrone, along with other organic pollutants (atrazine and isoproturon), was determined by RodriguezMozaz et al. [57], with an optical immunosensor in real water samples. The European Union (EU) is funding the development of new biosensing strategies for the control of hormone residues in an effort to improve food quality controls and to protect public health against the adverse effect of these substances. As a model of example, in the framework of the EU project "Development of single and multianalyte affinity sensors for rapid detection of androgen residues in live an post-mortem animals" (RADAR) (<http://intel.ucc.ie/>), a group of researchers are developing single and multi-analyte affinity sensors and receptor-based sensors for the rapid detection of androgens such as testosterone and metabolites [58]. 


\section{PCBs}

Polychlorinated biphenyls (PCBs) are ubiquitous environmental pollutants widely used as industrial chemicals, particularly as dielectric fluids in electrical transformers and capacitors. The high toxicity of some PCB congeners represents a risk for public health as these compounds are still present in the environment, even though the production of PCBs has been banned in several countries many years ago. Different biosensor configurations have been designed to determine PCBs in the environment, and these include the DNA biosensor with chronopotentiometric detection [59], and various immunosensors with fluorescence [60], SPR [61], and electrochemical [62] detection principles.

\section{Dioxins}

Apart from PCBs, other polychlorinated compounds of environmental concern are the dioxins, which are released as by-products in a number of chemical processes involving chlorine. Thus, processes such as the production of some pesticides, the manufacture of PVC plastics, the chlorine bleaching of pulp and paper and waste incineration generate dioxins. They are considered carcinogenic and are a potential threat to human health [63], and more recently, they have been included in lists of potential EDCs [61]. Conventional dioxins analysis requires laborious multistep clean-up procedures that increase the cost of each analysis. A significant number of immunoassays for dioxins have been developed in an effort to provide simplified and routine analysis [63-65]. The SPR biosensor developed by Shimomura et al. [61] for the determination of PCB (mentioned above) was also employed in the determination of the dioxin 2,3,7,8-TCDD. Similarly, another biosensor for detection of dioxin-like chemicals (polyhalogenated dioxins, furans, and biphenyls) based on a recombinant mouse hepatoma cell line was characterized and optimized by Pasini et al. [66].

\section{Phenols}

Phenolic compounds that appear in the environment originate from the paper and pulp industry and from the production of drugs, dyes, and antioxidants. Phenolic compounds, and especially chlorophenols, are important environmental pollutants because of their high toxicity and possible accumulation in the environment [67]. They are also considered as precursors of the dioxins [68]. Parellada et al. [2] developed an amperometric biosensor, with tyrosinase (a polyphenol oxidase with a relatively wide selectivity for phenolic compounds) immobilized in a higrogel on a graphite electrode, which correlated satisfactorily with the official method for the determination of the phenol index in environmental samples. Chlorophenols have been also detected with a flow-injection chemiluminescence fiber optic biosensor [67], exploiting the ability of certain substituted phenols to enhance the chemiluminescence reaction of luminol, catalyzed by horseradish peroxidases. Finally, a Lux-based biosensor was used to assess the toxicity of a paper mill sludge being some metals $(\mathrm{Cd}$ and $\mathrm{Cu}$ ) and pentachloro-phenol (PCP) [69].

\section{Surfactants}

Detergent products use surfactants as the basic "active" component. The anionic surfactants are the most widely used, while the cationic surfactants represent only $5 \%$ of the total [70]. An amperometric biosensor for detection of anionic surfactants was constructed with Pseudomonas rathonis $T$ (bearing a plasmid for surfactant degradation) as a biological element. Oxygen consumption acted as an indicator of cell metabolism and thus of the surfactant content of the sample. The limit of detection achieved for sodium dodecyl sulfate (SDS) was within $0.25-0.75 \mathrm{mg} / 1$ [71]. Taranova et al. [72] also studied the sensitivity and selectivity of biosensors based on bacterial strain Pseudomonas and Achromobacter and their ability to degrade the anionic surfactants. The degradation of surfactants by the bacteria caused a decrease in dissolved oxygen and a change in the oxygen electrode current. The microbial biosensor en- 
abled detection of surfactants with high selectivity, sensitivity, and reproducibility. The lower limit reached for SDS was near $0.25 \mu \mathrm{g} / \mathrm{l}$.

Since the 1960s, a new formula with more biodegradable surfactants such as alkylbenzene sulphonates (ASs) was introduced. Linear alkylbenzene sulfonates (LASs) are abundantly used in the formulation of household detergents. Despite the efficient removal of LASs in wastewater treatment plants, residues of LASs are still present in surface waters at the low $\mu \mathrm{g} / \mathrm{l}$ range [73]. Even though LASs are not severely toxic, they contribute to the permeation of other pollutants into aquatic animals [74]. A combination of two whole-cell biosensors was applied to river water samples for the determination of anionic surfactants [74]. The first biosensor was based on the detection of the dissolved oxygen consumed in the degradation of LASs by immobilized LAS-degrading bacteria. On the contrary, the other sensor, which used T. cutaneum yeast, did not respond to LASs. Values for LAS concentrations derived from the combined use of both biosensors correlated well with values determined using conventional methods.

Alkylphenol ethoxylates (APEs) belong to the group of nonionic surfactants, whose detection have gained more importance due to their endocrine-disrupting properties. APEs are used on a variety of industrial applications, such as manufacturing of pulp and paper, metals, textiles, paints, resins, adhesives, latex, rubber, and plastics. The APEs have been shown to be estrogenic both in vivo and in vitro. In wastewater treatment processes and in the environment, APEs degrade to alkylphenols (APs), which tend to be more toxic and show greater estrogenic activity. Rose et al. [75] described the development of a capillary-based immunoassay (CIA) for APEs and APs, utilizing glucose dehydrogenase (DH) as label.

\section{Alkanes, aromatic compounds, and polycyclic aromatic hydrocarbons (PAHs)}

Contamination of soils and surface and groundwater supplies with petroleum products is a serious environmental problem. Of particular concern for drinking water quality are water-soluble aromatic components (e.g., benzene, toluene, ethylbenzene, and xylenes) of petroleum products. Although many of these contaminants are readily biodegradable, they often persist in the environment [76]. A green fluorescent protein-based Pseudomonas fluorescens strain biosensor was constructed and characterized for its potential to measure benzene, toluene, ethylbenzene, and related compounds in aqueous solutions. The biosensor is based on a plasmid carrying the toluene-benzene transcriptional activator [76]. Another microbial whole-cell biosensor, using E. coli with the promoter luciferase luxAB gene, was developed for the determination of water-dissolved linear alkanes by luminescence [77]. The biosensor was used to detect the bioavailable concentration of alkanes in heating oil-contaminated groundwater samples.

PAHs are carcinogenic compounds generally formed during incomplete combustion or pyrolysis of organic matter containing carbon and hydrogen. They are very abundant, ubiquitous, and recognized carcinogenic compounds. Amperometric biosensors for naphthalene found in contaminated soils, were constructed using Sphingomonas yanoikuyae B1 [78]. For benzo(a)pyrene (BaP) and related adducts, a fiber optic fluoroimmunosensor has also been developed in which high sensitivity is achieved by laser excitation and optical detection [79]. The laser radiation reaches the sensor probe and excites the $\mathrm{BaP}$ bound to the fiber optic probe.

\section{Antibiotics}

Medical substances have been released into the environment with very little attention until recently. The presence of antibiotics in the environment is worrying since they promote antibiotic resistance. The increasing use of antibiotics for therapeutic purposes or as growth promoters in dairy cattle and as feed additives in fish farms or in livestock during the last five decades has caused a genetic selection of more harmful bacteria, which is a matter of great concern [80]. The widespread administration of antibiotics raises significant food safety issues since antibiotic resistance can be transferred to humans on inges- 
tion of affected meat and milk products [81]. Therefore, most of the biosensors developed are aimed at determining them in biological or food samples. For example, a commercial biosensor BIACORE 3000 was used to study the cross-reactivity between two sulfonamides (a group of antibiotics): sulfamethazine and furosemide [82]. Sulfonamides sometimes cause allergic reactions, whereas their effect in the human inmunosystem is of high interest for their therapeutical application. Sulfamethazine has been also determined with an optical immunosensor by Akkoyun et al. [83] in animal urine. Hansen and Sorensen [84] presented three different reporter gene systems from V. fischeri, E. coli, and Aequorea victoria all combined with a tetracycline inducible promoter in the development of three corresponding whole-cell biosensors. They respond to low levels of tetracyclines by producing galactosidase, light or green fluorescent protein, respectively. In the field of food monitoring, different biosensors were able to determine penicillin G [81] or tetracyclines [84], both in milk. More references of biosensors for antibiotic determination can be found in a review by Patel [4].

\section{Toxins}

Toxins are a very heterogeneous group capable of affecting different biochemical processes including membrane function, ion transport, transmitter release, and DNA and protein synthesis. In many cases, specific details of the site and mode of action of a toxin at the molecular level are not known. A number of attempts have been made to detect toxins in environmental and clinical samples using receptor sensors [85]. The induction of reporter genes by a promoter, which responds to a wide variety of toxic compounds, can be used to produce biosensors useful as first indicators of the presence of pollutants in the environment. When the cells are exposed to toxic substances, there can be either a reduction (negative signal) or an activation (positive) in reporter-protein production [86]. Toxin-sensitive cells that express a reporter gene can be used, therefore, as a biosensor for the nonspecific detection of toxics, but not for a specific toxin.

A great number of specific sensors for bacterial toxins and mycotoxins have been developed for food and environmental control [87-91]. Thus, an integrated optical sensor has been reported for the analysis of aflatoxin B in corn [92]. A light-addressable potentiometric immunosensor based on the commercial device $\left(\right.$ Threshold $^{\circledR}$ ) for the analysis of saxitoxin and ricin has also been described. An impedance-based immunosensor has been prepared by using an ultrathin platinum film with an immobilized layer of antibodies against the staphylococcal enterotoxin B [93]. Various evanescent wave immunosensors have also been reported to be capable of detecting botulin with very low limits of detection [94]. A rapid and sensitive immunosensor for the detection of the Clostridium botulinum toxin A has also been developed. This fiber optic-based biosensor utilizes the evanescent wave of a tapered optical fiber where antibodies antitoxin A have been covalently immobilized at the distal end. The toxin could be detected by means of a rhodamine label, within a minute at concentrations as low as $5 \mathrm{ng} / \mathrm{ml}$. The reaction was highly specific, and no response was observed against tetanus toxin [95]. With a similar configuration, it has been described for the detection of the cholera toxin [96]. A portable fiber optic biosensor for quantification of the staphylococcal enterotoxin B in diverse media has also been described [97].

\section{Microorganisms}

Bacteria, viruses, and other microorganisms are found widely in polluted, untreated, and treated waters, which implies a worldwide public health problem. In the case of untreated water systems, fecal coliforms may enter rivers and streams through agricultural runoff and nonpoint source pollution [98] and via domestic wastewater. Pathogenic compounds may reach humans by various routes, such as the use of these waters for recreation or sports, for the irrigation of fruit and vegetables and as drinking water. Therefore, surface waters may play an important role in the transmission of pathogens. Suitable monitoring of the water supply for the presence of pathogens can assist in preventing disease from these 
sources [99]. Current methods for detection of pathogenic viruses, bacteria, protozoa, and helminths tend to be inaccurate, time-consuming, and expensive. As a result, indicator bacteria such as Salmonella, "total fecal coliforms", and "total fecal streptococci" are commonly used to determine the risk of fecal contamination and the possible presence of pathogens in water and wastewaters [100]. Other emerging pathogenic microorganisms, Campylobacter, Aeromonas, and Yersinia genera [101] and in recent years, also bacteriophages, have been proposed by several groups as indicators for the microbial quality of water since they are more suitable to signal viral contamination of water sources [102]. On the other hand, monitoring of microorganisms is not only of environmental concern; from a military point of view, there are a number of pathogenic bacteria that can be considered possible biological warfare agents [103].

Conventional analytical methods for microorganisms are based on colony-forming unit (CFU) count and require selective culture, biochemical, and serological characterization [104]. In most cases, they require also some enrichment steps. These methods are sensitive and selective, but time-consuming: days to weeks are needed to get a result. The increasing public concern over environment safety has led to a search for technologies capable of rapidly identifying contamination problems at source. Biosensors capable of detecting an organism quickly will be important in the environmental monitoring of pathogens in real time. The microbial content of a sample can be determined by monitoring microbial metabolism. The transducer can either detect consumption of oxygen or the appearance/disappearance of an electrochemically active metabolite [103]. However, proliferation of nucleic acid and immuno-based detection technologies has provided sensitive and specific detection systems for pathogenic bacteria and viruses. DNA detection may be more specific than immunologically based detection, and the sensitivity can improve thanks to its combination with polymerase chain reaction (PCR) methods. Gene probes are already finding application in detection of disease-causing microorganisms in water supplies, food, or in plants, animal or human tissues [103]. Immunological detection, on the other hand, is faster and more robust than DNA detection. Moreover, it has the ability to detect not only contaminating organisms, but also their biotoxins [105]. Koubaka et al. [106] reported detection of Salmonella enteriditis and Listeria monocytogenes in real time using an SPR sensor based on antibodies immobilized on the gold sensor surface. Salmonella and Listeria were detected by the sensor at concentrations down to $10^{6}$ cell $/ \mathrm{ml}$. Recently, a number of piezoelectric biosensors formats have been developed for the detection of several microbial contaminants [107]. Salmonella typhimurium detection in liquid samples by an immunosensor based on the acoustic wave principle was reported by Pathirana et al. [107]. Limits of detection were around 100 cells $/ \mathrm{ml}$ in less than $2 \mathrm{~min}$. In another example of piezoelectric biosensors, 23-mer biotinylated probes sequence, specific to Aeromonas hydrophila, were immobilized onto the surface of a streptavidin-coated gold surface of a quartz crystal [108]. This sensor was capable of detecting a PCR product amplified from a specific gene of A. hydrophila and of distinguishing between samples that contained the gene and samples that did not. Ercole et al. [104] described a biosensor for the determination of $E$. coli in water samples by an immunochemical potentiometric alternating biosensor. The monitored change in the redox potential was due to the production of $\mathrm{NH}_{3}$ by a urease-E. coli antibody conjugate linked with the $E$. coli cells present in the water. Hasebe et al. [109] described an amperometric tyrosinase-based biosensor for the detection of $E$. coli in wastewater. The detection was based on tyrosinase-catalyzed oxidation of polyphenolic compounds, which are produced microbiologically from salicylic acid, and the subsequent signal amplification. The sensor was capable of detecting $10^{3}-10^{4}$ cells $/ \mathrm{ml}$ after an enrichment step.

The commercialization of current research in biosensor technology will provide consumers with real-time biosensors capable of maintaining sensitivity better than $100 \mathrm{CFU} / \mathrm{ml}$. Industries such as Caliper Technologies, Cepheid, Nanogen, ACLARA BioSciences, MICROGEN Systems, and Lawrence Livermore Laboratories are developing microfabricated systems for detection and identification of specific microbial agents [105]. Advances in antibody production and the recent emergence of phage-displayed peptide biosensors offer increased possibilities for the rapid detection of pathogens [110,111], but still require time-consuming preenrichment in order to detect low numbers of pathogens in water [112].

(C) 2004 IUPAC, Pure and Applied Chemistry 76, 723-752 


\section{Metals}

The determination of traces of heavy metals such as $\mathrm{Cu}, \mathrm{Cd}, \mathrm{Hg}$, and $\mathrm{Zn}$ in the environment is very important because of their high toxicity, their increasing environmental levels (due to their use in industrial processes), and because metals can bioaccumulate in living organisms, especially in marine organisms [113]. Metals are usually determined after digestion with strong acids. Common analytical techniques used are ion chromatography, inductively coupled plasma, and polarography [114]. Heavy metals can also be determined with ion-selective electrodes. However, these methods are not able to distinguish between available (potentially hazardous) and nonavailable (potentially nonhazardous) fractions of metals to biological systems [115]. One advantage of the whole cell-sensors is their ability to react only to the available fraction of metal ions. Recent progress has been made in the development of biosensors relying on intact bacterial cells to monitor toxic metals. Both nonspecific and specific biosensors that utilize intact cells have been developed for this purpose [86]. Nonspecific microbial biosensors, which have been used for several years, measure only general toxicity, such as the alreadymentioned Cellsense. On the other hand, heavy metals are well known to inhibit the activity of enzymes, and application of this phenomenon to the determination of these hazardous toxic elements offers several advantages such as simplicity and sensitivity. Besides, in many cases, the inhibition effect is related to its biological toxicity [113]. Durrieu and Tran-Minh described a biosensor for the determination of heavy metals based on inhibition of the AP present on the external membrane of Chlorella vulgaris microalgae. The microalgae cells were immobilized on removable membranes placed in front of the tip of an optical fiber [114]. Krawczynski vel Krawczyk et al. [113] studied the inhibition effect of mercury and other heavy metal ions on urea hydrolysis catalyzed by urease immobilized in a polyvinyl chloride (PVC) layer at the surface of a pH electrode in the form of potentiometric biosensor. Urease is the most frequently applied enzyme for inhibition determination of mercury, as it is relatively cheap and easily available. Because the method was not specific, it was applied for the determination of the total inhibition effect caused by heavy metal ions in water samples. The application of another urease-based optical sensor for monitoring low levels of mercury has also been reported by Yerian and Ruzicka [116]. Urease immobilized into Nafion film on the surface of an ion-sensitive field transistor (ISFET) was also used for heavy metal measurement by Volotovsky et al. [117]. In this approach, enzyme immobilization into a negatively charged polymer seemed to cause an increase in the inhibition effect of metals due to cation accumulation in the polymeric matrix. A combination of specific additives and selective rewashing techniques to make the urease-based biosensor sensitive only to mercury ions was proposed.

For the determination of a specific metal, recombinant bacterial sensors have been constructed and used. Specific biosensors, based on inducible promoters fused to reporter genes (e.g., those that code for bioluminescence proteins, such as luciferase), are more sensitive than both chemical analysis methods and nonspecific toxicity biosensors [118]. The light emitted can be detected by photometers, illuminometers, and charge-coupled devices [86]. Recombinant luminescent bacterial sensors were used by Ivask et al. [119] for the determination of the bioavailable fraction of cadmium, zinc, mercury, and chromium in soil. In this work, two bacterial recombinant heavy metal sensors were constructed based on two different receptor-reporter systems: one was inducible by $\mathrm{Zn}^{2+}, \mathrm{Cd}^{2+}$, and $\mathrm{Hg}^{2+}$, and the other by $\mathrm{Cr}(\mathrm{VI})$ and $\mathrm{Cr}(\mathrm{III})$. The bacterial sensors used were not perfectly specific to one heavy metal, but responded to some "nontarget" metals as well. In another example, the mer-lux gene fusion in $E$. coli was used to estimate bioavailable mercury in soil. The bioavailable fraction was defined here as being part of the water-leachable fraction. The mer-promoter was activated when $\mathrm{Hg}(\mathrm{II})$, present in the cytoplasm of the biosensor bacterium, binds to MerR, resulting in transcription of the lux genes and subsequent light emission [115]. The luminescence-based bacterial sensor strains Pseudomonas fluorescens OS8 (pTPT11) and Pseudomonas fluorescens OS8 have also been used for mercury and arsenite detection, respectively, in soil extracts [118]. Soil samples were extracted with water, ammonium acetate, hydrogen peroxide, and nitric acid, and the results obtained were compared with those attained with traditional methods. 
Other biosensors have been designed, based on bioengineered proteins. In these cases, the biosensor monitors conformational changes caused by the binding of the metal ion to the engineered protein [120]. Bontidean et al. [121] used mercuric ion-binding regulatory proteins as the biological part of the biosensor, MerR. The conformational change resulting from the binding of the metal ion to the protein caused a change in the capacitance, which was proportional to the concentration of the metal ions determined.

\section{Inorganic phosphate}

Inorganic phosphate found in surface waters is used as a measure of the degree of eutrophism. Traditional methods for its determination are chromatography, volumetric titration, or spectrophotometry. Therefore, the development of simple and fast biosensors represents an interesting alternative to them. Various enzymatic phosphate biosensors for phosphate determination have appeared in the literature in recent years $[122,123]$. Parellada et al. [2] described a configuration based on the sequential action of three enzymes that opens up a way to the construction of reagentless enzymatic phosphate sensors.

\section{Nitrate}

The increasing nitrate levels found in ground and surface waters are of concern because they can harm the water environment. In line with this, urban wastewater treatment regulations aim to reduce pollution, including nitrate pollution, from sewage treatment works and industry. A biosensor containing immobilized denitrifying bacteria was applied for the determination of $\mathrm{NO}_{3}{ }^{-}$in tap water. Through the reduction of $\mathrm{NO}_{3}{ }^{-}$in a reaction chamber, $\mathrm{N}_{2} \mathrm{O}$ was formed and determined by a $\mathrm{N}_{2} \mathrm{O}$ microelectrode, which was the sensing element of the biosensor [124]. A microscale biosensor for nitrate/nitrite determination was used for in-site monitoring in an activated sludge plant. The biosensor was based on the diffusion of nitrate/nitrite through a tip membrane into a dense mass of bacteria converting the ions into nitrous oxide with subsequent electrochemical detection [125].

\section{Biochemical oxygen demand}

Biochemical oxygen demand $\left(\mathrm{BOD}\right.$ or $\mathrm{BOD}_{5}$ ) is defined as the oxygen required to neutralize organic wastes over 5 days at $20^{\circ} \mathrm{C}$, and is a parameter widely used to indicate the amount of biodegradable organic material in water [126]. The conventional BOD test has certain benefits such as being a universal method of measuring most wastewater samples, and, furthermore, no expensive equipment is needed. It has, however, the limitation of being time-consuming, and consequently it is not suitable for online process monitoring. Thus, it is necessary to develop an alternative method that could circumvent the weakness of the conventional BOD test [127]. Fast determination of BOD could be achieved by biosensor-based methods. A common feature of these sensors is that they consist of a microbial film that can biooxidize the organic substrate to be quantified, sandwiched between a porous cellulose membrane and a gas-permeable membrane as the biological recognition element. The response is usually a change in concentration of dissolved oxygen or other phenomena such as light emission [127]. Most BOD sensors rely on measuring the bacterial respiration rate in close proximity to a transducer, commonly Clarktype (an amperometric sensor for measuring dissolved oxygen developed by Clark in 1956 [127]).

Some BOD sensors have been developed and marketed by various manufactures in both biofilm and bioreactor-type configurations. Most commercially available BOD sensors are flow-type systems that can be more easily automated, but generally require high maintenance to prevent fouling and clogging [128]. Instrument information about many BOD commercial biosensors was provided by Liu and Mattiason [127]. Despite the good agreement between biosensor results and conventional BOD analysis, and despite the short response time of biosensors, current BOD biosensor systems still present a series of limitations that restrict their industrial applicatios: the lack of standardization and legislation in 
most countries, complicated maintenance requirements, and insufficient resistance to various toxic compounds such as heavy metal ions, $\mathrm{CN}^{-}$and phenol in the wastewater. It is possible to eliminate the toxic effects of heavy metal ions by using a chelating agent that complex the ions, e.g., ethylene diamine tetra-acetate (EDTA) and sodium diethyl dithiocarbamate (DDTC) [129,130]. Prevention of contamination by other microbes is also important for a reliable biofilm-type BOD sensor [127].

Many BOD biosensors have been developed for the determination of high BOD values in industrial wastewater and not adapted to the measurement of low BOD values [126]. An optical fiber biosensor was developed for the evaluation of low BOD values in river waters by Chee et al. [131]. The immobilized Pseudomonas putida bacterium membrane was placed on the top of an optode, which was linked to a photodiode that detected fluorescence signal. The response time was $15 \mathrm{~min}$ for chloride up to $1000 \mathrm{mg} / \mathrm{l}$.

\section{Bioremediation}

Bioremediation is an application of the microbial capacity to transform complex organic molecules into simpler inorganic constituents. Parameters such as nutrient availability, metal ions, $\mathrm{pH}$, dissolved oxygen, and temperature, influence the growth of bacteria. Biosensors that can monitor these parameters will help to better control the bioremediation process. Different molecular biosensors implemented to monitor these parameters were reviewed by Purohit [132]. These biosensors use the luciferase expression system. The biological component in this molecular biosensor is a recombinant plasmid. It has a specific promoter, whose expression is sensitive to a target molecule.

\section{Biosensors as detectors of separation methods}

Although chemical separations can be highly efficient, some mixtures are too complicated to be separated by chromatography. At the same time, biosensors suffer often from lack of selectivity in the determination of certain compounds. The combination of these two methods can enable identification of molecules that are not detectable separately by either method [133]. Components are thus identified by both functional recognition and separation retention time [134,135]. A review by Fishman et al. presented examples and principles of combining chemical separation with biosensor detection using living systems, whole cells, membrane receptors, enzymes, and immunosensors [133].

\section{COMMERCIAL BIOSENSORS}

Despite the high number of biosensors under development and also the amount of research literature on this area, few practical systems are currently enjoying market acceptance. The first successful commercial biosensor was the "glucose pen", launched by Exactech in 1987. Nowadays, $90 \%$ of sales come from glucose-detecting biosensors for medical applications [98]. However, in other areas such as in food, agriculture, military, veterinary, and the environment, there is a potential market still to be established. Many of the instrumentations developed for the medical diagnostics market could be adapted for environmental market, for example [1]. Even though commercial returns from environmental biosensors are substantially less than from medical diagnostics, public concern and government funding has generated a major research effort [136] aimed at the application of biosensors to the measurement of pollutants and other environmental hazards.

A list of commercially available biosensors for the determination of different pollutants is shown in Table 2. SPR biosensors constitute the most successful type in the commercial instruments for environmental monitoring. The pioneers of SPR-based biosensing were Pharmacia Biosensor AB, now BIACORE AB (Uppsala, Sweden), who launched the original BIAcore system in 1990. The company

(Text continues on p. 741.) 


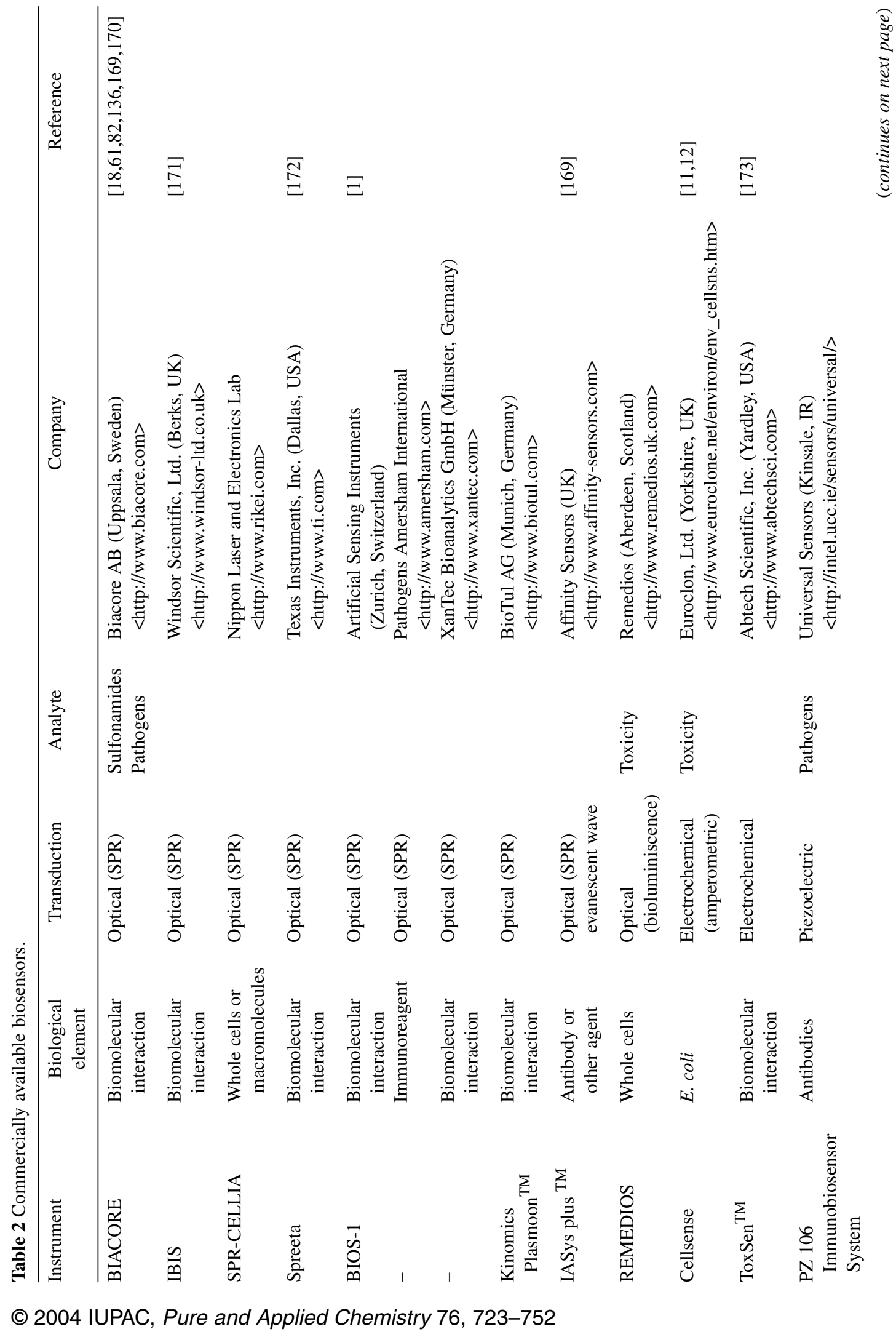


S. RODRIGUEZ-MOZAZ et al.

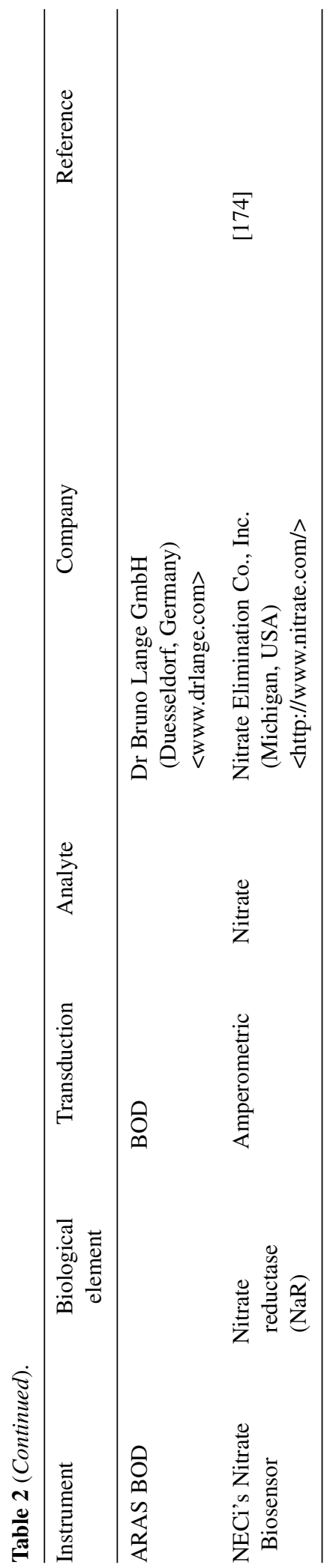


now has a large range of biosensors, which includes several generations of the original BIAcore (series 1000,2000 , and 3000) as well as other configuration systems offering varying degrees of automation and parameter specifications [112]. The BIACORE 3000 biosensor, which is based on SPR principle, monitors biomolecular interactions as they proceed over time. The advantage of the method is that there is no need for labeling the interactants [82]. Approximately $90 \%$ of the 1998 and 1999 commercial biosensor publications cite the use of BIACORE instruments [137]. Other SPR commercial biosensors are provided by Windsor Scientific, Ltd. (Berks, UK), which markets the IBIS system; and by Nippon Laser and Electronics Labs (Hokkaido, Japan), which markets CELLIA sensor. CELLIA systems can be configured for either whole cells or macromolecules. Texas Instruments (Dallas, TX) integrates SPR detector Spreeta that can be configured for industrial, environmental, and biological applications. BioTul AG (Munich, Germany) launched its Plasmon SPR instrument in August 1999 [137]. On the other hand, Affinity Sensors (Franklin, MA) manufactures the IAsys line of instruments, which use evanescent wave technology. In contrast, REMEDIOS, a whole cell-based biosensor, can be employed for diagnosis of contaminated lands or soils. It detects the levels of any toxicity that affects the metabolic activity of the biosensor organisms. Under normal conditions, the biosensor gives out visible light. The light output is directly proportional to the metabolic activity. If the sample (water, soil, sediment, or sludge) has any available toxicity, the bioluminescence will decrease in direct proportion to the level of toxicity. Biosensor organisms are selected as representative of bacterial strains found in the environment as well as those that are involved in bioremediation processes.

\section{FUTURE PERSPECTIVES}

In spite of the past and current large amount of research in biosensor development, there is still a challenge to create improved and more reliable devices. This section presents foreseeable future trends in biosensor research activities.

\section{Nanotechnology}

Nature is full of intricate nanosystems, far more advanced than all of the man-made systems [138]. A significant effort is being made nowadays to either mimic or use such systems in the development of new applications and devices such as sensors and biosensors. In order to improve biosensing interfaces, design and analysis on the molecular level have been proposed. All are addressing biointerfaces in molecular dimensions and thus can be summarized by the term "molecular nanotechnology" [139]. Therefore, there is a trend toward the combination of physics and biology in the creation of new nanostructures. Nanotechnology comprises a group of emerging techniques from physics, chemistry, biology, engineering, and microelectronics that are capable of manipulating matter at nanoscale. This novel technology bridges the gap between materials science, coming from the micrometer range, and biochemistry/chemistry, where individual molecules are of major interest [140].

Inspired by nature, molecular self-assembly has been proposed for the synthesis of nanostructures capable of performing unique functions. Self-assembly is the formation of organized, patterned structures without external direction. Biomaterials, such as proteins, lipids, and nucleic acids, can self-assemble $[139,141,142]$. Such nanostructures are applied for the development of amperometric immunosensors. Tiefenauer et al. [143] have developed a nanostructured gold film electrode with openings where the biotinilated antigen is bound to the capture molecule streptavidin (covalently immobilized on silica). The close contact of the recognition and redox centers to the electrodes is designed to facilitate electron transfer. Several research groups have begun to explore alternative strategies for the development of optical SPR biosensors based on the extraordinary optical properties of metal nanoparticles $[144,145]$. Metal nanoparticles that differ in size and composition can be designed as well, to scatter light of different wavelengths according to their distinct SPR [146]. Cao et al. [147] showed how oligonucleotides and presumably other biomolecules (e.g., proteins) can be used to modify the surfaces 
of such particles, thereby imparting useful biorecognition properties to them. For example, Lazarides et al. [148] have developed gold colloidal nanoparticle aggregates that are linked by short pieces of DNA. These materials exhibit a color change from red to blue after DNA hybridization. This color change is due to electromagnetic coupling between the gold nonspherical nanoparticles.

Lundstrom et al. [138] have proposed the use of pigment-containing cells (present in the skin of certain fishes and frogs) as biosensors. The cell membrane receptors, the G-protein coupled receptors, control the pigment particles aggregation, which is simple to measure. This natural nanosystem shows large promise for new biosensing and bionanalytical systems since, through several biochemical modifications, G-protein coupled receptors of almost any kind can be provided.

\section{Multianalyte determination}

Development of sensors capable of determining several analytes simultaneously can represent an interesting tool in environmental monitoring and screening [57]. This configuration allows the reduction in time and sample volume and other reagents required. Different technologies have been developed in recent years to produce multianalyte sensors. The development of large-scale biosensor arrays composed of highly miniaturized signal transducer elements, for example, enables the real-time parallel monitoring of multiple species and is an important driving force in biosensor research [144]. In clinical diagnosis, simultaneous determination of multiple analytes has been a great challenge [149]. Multichannel biosensors are required for direct detection in high-throughput screening systems in the search for new pharmaceuticals. An example of multichannel performance is the biosensor proposed by Berger et al. [150] using BIAcore system that demonstrates the feasibility of a multisensing device for monitoring four separate immunoreactions simultaneously in real time. A planar array immunosensor equipped with a charge-coupled device (CCD) as a detector and a diode laser as light source, has been also developed and applied to either the determination of multiple compounds, such as virus, toxins, and bacterial spores in a single sample analysis or a single analyte in multiple samples simultaneously [151-153].

For environmental applications, a multianalyte enzyme biosensor based on a disposable, thickfilm multielectrode was developed for the analyte discrimination of binary mixtures of the pesticides paraoxon and carbofuran [154]. Other studies aimed at the development of multianalyte immunosensors, such as that described by Gonzalez-Martínez et al. [3], which developed a competitive capture assay for carbaryl, atrazine, and irgarol 1051 as target compounds. Mastichiadis et al. [155] have applied recently an optical capillary immunosensor to the simultaneous determination of the pesticides mesotrione, hexaconazole, paraquat, and diquat, by preparing an ordered array capillary of four distinct analyte bands. After the optimal characterization of analytical conditions in deionized water, further experimentation is required in order to apply the biosensor to natural water sample analysis. Barzen et al. [156] and Rodriguez-Mozaz et al. [57] have described the application of a multianalyte immunosensor based on total internal reflection fluorescence (RIANA), to the simultaneous determination of different analytes in the same sample (see Fig. 1). Atrazine, isoproturon, and estrone were successfully determined in natural water samples with this biosensor [57]. 
Fluorescent light

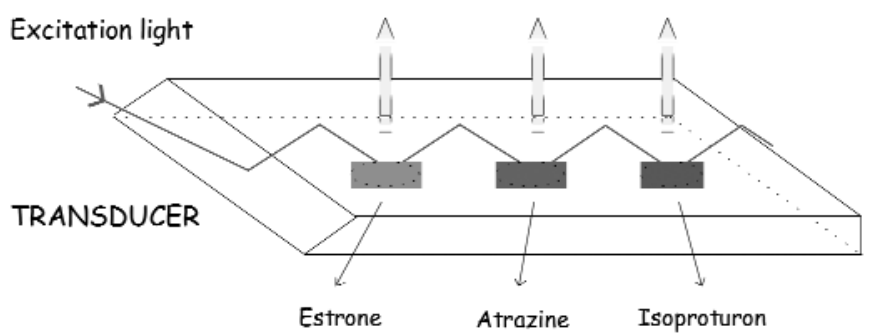

Fig. 1 Optical multianalyte transducer. Excitation light is totally internal reflected along the transducer. In each point of reflection or sensing area, the corresponding analyte (estrone, atrazine, isoproturon) is determined by simultaneous but spatially resolved independent solid-phase immunoassays.

\section{Miniaturization}

In general, there is a growing tendency toward miniaturization of analytical systems, since it allows the handling of low-volume samples, a reduction in reagent consumption and waste generation, and increases sample throughput [157]. Taking advantage of miniaturization benefits, sensors and biosensors can become inexpensive and easy-to-handle analytical devices for fast, reliable measurements of chemical species. Miniaturization emerges thus as an important aspect of future bioelectronics. Biosensor miniaturization has a particular significance for medical applications when sometimes an implantable sensor is desired for continuous in vivo monitoring [158], and for pharmaceutical industries, in the field of high-throughput screening [120]. For environmental monitoring, the size of a sensor is usually not so important, and there is not an obvious need to produce miniaturized systems. However, the use of a miniaturized flow cell and a microsensor will become a key technology, reducing the amount of used chemicals, which will have an impact not only on the environment, but also on the economy [158]. There is, in fact, an increase in the demand on environmental analysis and also the amount of chemicals to be determined. The time and expense devoted to the detection of environmental pollutants are becoming impediments in treating a number of samples for many environmental projects. In this sense, microfabricated sensors or systems will become a powerful tool [158]. On the other hand, a small size would be preferred in the design of portable biosensors, especially for on-field screening applications. Another advantage of miniaturization at the nanometer-scale level is that it will allow high-density information storage.

This miniaturization trend involves adaptation of microfabrication and nanofabrication techniques. In addition, the practical application of any sensor requires the use of complete analysis systems for sample handling such as pumps, filters, membranes, and sample conditioning [120]. Such formats may be used in bioanalytical microsystems that comprise another new trend in bioanalysis. In such microfluidic systems, miniaturized biosensor arrays, as well as miniaturized sampling, filtering, and so on, has to be accomplished [120].

\section{Mass production}

Technologies usually enable not only miniaturization, but also batch-fabrication, which leads to the production of inexpensive sensors [158]. Automated manufacturing technologies are required in the commercial production of large numbers of inexpensive, reproducible biosensor devices. Mass fabrication methods have enabled biosensors to be produced in large volumes for clinical markets. Two techniques borrowed from the electronics industry have proved particularly important: screen-printing (ink is pressed through a mask to form a pattern on a ceramic or plastic base) and photolithography (a photoresistant material is exposed to ultraviolet light passed through a mask and then the silicon is chemi- 
cally etched). [7]. Silicon fabrication technology has been preferred as a means of mass production of biosensors. This is an area of intense research activity mainly by diagnostics companies. The use of silicon microfabrication for both electrochemical and optical sensors is expanding, and the capability of on-chip electronic signal amplification and data processing are very attractive. Bookham Technology (Oxfordshire, UK) is using microelectronics technology based on silicon to produce optical chips for biosensor application [1]. Other techniques such as air-brush and Cabro deposition have been adapted for biosensor fabrication, especially for thick-film biosensors. Thin-film sensors are generally produced by a variety of vapor deposition techniques, electrochemical methods, and more recently by the use of Langmuir-Blodgett technology. These have been used in the production of sensors based on SPR [1]. Laser desorption is particularly promising and offers the ability to "write" proteins to surface with very high resolution (patterning) [159].

\section{Network systems}

The future integration of wireless communications systems will generate huge interest as this will inevitably lead to the emergence of extensive networked multiple autonomous analytical stations in rivers, lakes, wells, or even water treatment plants. These units will provide high-quality information about key chemical parameters that determine the quality of our environment [157]. By means of this network system and by an intelligent remote surveillance, an active response will be possible. To accomplish this, there is a need for robust and unattended working analytical instrumentation. Each unit will be portable, plug-and-playable, user-friendly, and fully automated with little need for maintenance. The emergence of these compact, self-sustaining, networked instruments will have enormous impact on all field-based environmental measurements including biosensors. Gu et al. [15] have recently applied a novel early warning protocol to monitor the toxicity of the effluents of a water treatment plant. A toxicity early warning system is needed to prevent the outflow of water containing dissolved toxic chemicals [15] and is important to ensure compliance with EU directives.

\section{Validation}

Despite the practical advantages of biosensors, they must be able to provide results in real time, must be simple to use, portable, and cost-effective [4]. Acceptance of these methods is dependent upon several factors: they should be comparable to conventional analytical systems in terms of reliability, sensitivity, selectivity, specificity, and robustness. Therefore, biosensor measurements have to be verified by comparing them with the results of chemical analysis [77], as shown in Fig 2. This verification process is known as validation. Method validation is the process of demonstrating that the combined procedures of sample preparation (extraction, clean-up, etc.) and analysis will yield acceptably accurate, precise, and reproducible results for a known analyte in a specific matrix [160]. Thevenot et al. [161] recommend several analytical parameters needed to define in order to characterize biosensor performance. They include four sets of parameters: (i) calibration characteristics: sensitivity, working and linear concentration range, limit of detection (LOD) and of quantification (LOQ); (ii) selectivity and reliability; (iii) steady-state, and transient response times and sample throughput; (iv) reproducibility, stability, and lifetime.

The overall commercial status and general acceptance of the technology will depend on the performance characteristics, sample throughput, associated costs, and acceptance by regulatory authorities, based on independent validation data generated using internationally recognized procedures (e.g., AOAC, ISO, and IDF) [4]. 


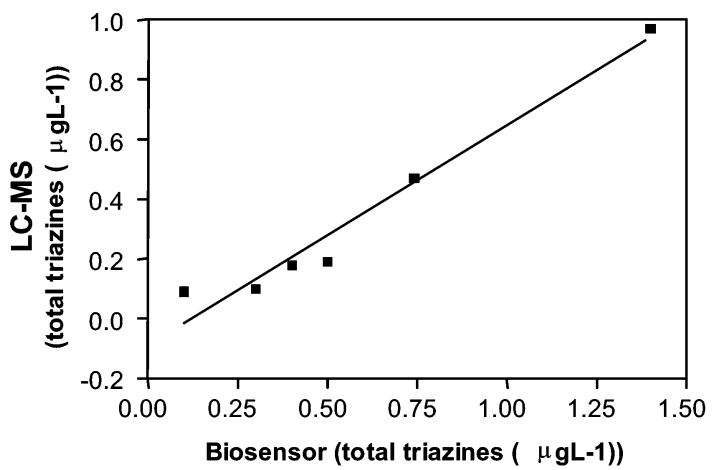

Fig. 2 Correlation between results obtained by an immunosensor and those obtained by LC/MS, in the determination of triazines in river water. From Mallat et al. [41]. Reprinted with permission from American Chemical Society.

\section{Bioengineering}

Biosensor sensitivity and selectivity depend essentially on the properties of the biorecognition elements to be used for analyte binding. Genetic engineering provides an elegant way not only for providing unlimited amounts of biorecognition molecules, but also for the alteration of existing properties and the supplementation with additional functions [18]. The current generation of biosensors is taking advantage of novel biosensing materials based on gene engineering. In the field of biosensors, gene engineering focuses on two main fields: (1) genetically engineered receptor molecules and (2) genetically transformed cells.

Selective receptor units of the sensor are usually derived from subcellular components. The most commonly applied biomolecules are enzymes, antibodies, and receptors [162]. Current research includes combinatorial screening or design of the amino acid sequence of the binding region of antibody. In this sense, recombinant antibodies provide an emerging strategy in the development of new immunosensors [110]. A recently developed method that generates antibody-like molecules that bind specifically to target molecules is "phage display". Phage display affords a unique way of selecting peptides and proteins with binding affinity similar if not higher than monoclonal antibodies [105]. These techniques make possible the production of high amounts of affinity peptides or antibodies without the immunization and sacrifice of laboratory animals. Once isolated, the displayed peptide can be easily examined to determine its sequence and subsequently may be manipulated for improved stability or affinity. In phage display, a library of peptides or larger molecules, including antigen binding fragments (Fabs) or single chain fragment variables ( $\mathrm{scFVs}$ ), is encoded within a population of bacteriophage, which express them on the surface [105]. These libraries can be applied to select and isolated specific suitable antibodies or peptides for any antigen.

Different authors are now investigating the potential of using phage-displayed peptides as reagents in sensor applications. Benhar et al. [110], for example, presented single-chain phage-displayed antibodies combined with amperometric detection and its application as an immunosensor for the detection of three different analytes. Goldman et al. [111] demonstrated the potential of a phagebased biosensor for the determination of a staphylococcal enterotoxin B (SEB). A library of random 12-mers displayed on phage was panned against SEB. Whole phage was labeled with the dye Cy5, allowing fluorescence detection of the assay. Recombinant antibodies derived from antibody libraries with $s$-triazine selectivities were applied and modified by Hock et al. [18] for the development of suitable antibodies likely to be used in immunoassay or immunosensors.

Modified cell biosensors are constructed by fusing a reporter gene to a promoter element that is induced by the presence of a target compound. This genetic information, located on a plasmid vector, is then inserted into a bacterial strain, which may be integrated into the chromosome or remain in plas- 
mid form. The engineered genetic fusion is then replicated along with the cell's normal DNA [163]. As reported above, in the case of bioluminescence sensors, the recombinant bacteria employed contains gene fusions between the regulatory region of the mer operon $(\mathrm{merR})$ and bacterial luminescence genes, which respond to contaminants. Recombinant luminescent bacterial sensors were used by Ivask et al. [119] for the determination of cadmium, zinc, mercury, and chromium. When $\mathrm{Hg}(\mathrm{II})$, present in the cytoplasm of the biosensor bacterium, binds to merR, the mer promoter is activated, resulting in transcription of the lux genes and subsequent light emission. Three different whole-cell biosensors for the determination of mercury were made using E. coli by fusing the mercury-inducible promoter, Pmer, and its regulatory gene merR, with three different reporter genes producing light, $\beta$-galactosidase or green fluorescent protein, respectively, as response to the presence of low levels of mercury [164]. The same group presented the choice of three different reporter gene systems combined with a tetracycline-inducible promoter in the development of three different biosensors for the analysis of tetracyclines [84] as reported above.

\section{CONCLUSIONS}

Despite the huge potential of biosensors, and the ever-increasing number of biosensors developed, commercially available biosensors are being applied to a restricted area of the potential market. In general, biosensors for environmental analysis have several limitations: sensitivity, response time, and lifetime, which should be improved for them to become a competitive analytical tool. The areas of development that are expected to have an impact in biosensor technology are: immobilization techniques, nanotechnology, miniaturization, and multisensor array determinations. However, a crucial aspect may be the production of new sensing elements easy to synthesize and with the capability to broaden the spectra of selectivities that can be reached by a biosensor. At present, the preparation and production in large scales of biomolecules such as enzymes or antibodies need an investment of time and knowledge. Synthetic peptides and MIPs are contemplated as promising alternatives overcoming the above-mentioned limitations. Unfortunately, the affinity accomplished by these synthetic receptors is still several orders of magnitude below that of the antibodies. Improvement in the affinity, specificity, and mass production of the molecular recognition components may ultimately dictate the success or failure of detection technologies [2]. The possibility of tailor binding molecules with predefined properties, such as selectivity, affinity, and stability, is one of the major aims for biotechnology. The development of advanced receptors will allow the analysis of complex real samples and in situ measurements resolving the responses from the analyte and from nonspecific background effects. Since scientific attention is currently being given to biotechnology, as this review has pointed out, the development of improved molecular recognition elements will be followed by a corresponding enhancement of the biosensor features.

From the above viewpoint, it is clear that the future of biosensors will rely on the success of emerging sophisticated micro and nanotechnologies, biochemistry, chemistry, thin-film physics, and electronics. To reach this goal, an important investment in research, expertise, and the necessary facilities is needed [5]. However, as the world becomes more concerned about the impact that environmental contamination may cause on public health and the ecosystem, the demand for rapid detecting biosensors will only increase. Biosensors still need to achieve the confidence of potential users, having in mind that the commercialization of new devices will always be the best indicator of the success of a biosensor technology.

The analysis of complex matrices and of analytes difficult to determine by the actual analytical procedures (i.e., highly polar compounds), are progressively being approached by biosensors. However, there is still a lack of alternative biosensing systems for an important bunch of emerging contaminants such as bisphenol A, phtalates, and polybrominated compounds (used as flame retardants), veterinary and human medicines and personal care products (nutraceuticals, synthetic fragances, sun screen agents, etc.). 


\section{ACKNOWLEDGMENTS}

This work has been supported by AWACSS (EVK1-CT-2000-00045) and by RADAR (QLRT-200001670). Sara Rodriguez acknowledges Ministerio de Ciencia y Tecnología (Project PPQ 2000-3006CE) and I3P Program (Itinerario integrado de inserción professional; co-financed by CSIC and European Social Funds). María J. López de Alda acknowledges a Ramon y Cajal contract from the Spanish Ministry of Science and Technology.

\section{REFERENCES}

1. I. E. Tothill. Comput. Electron. Agric. 30, 205-218 (2001).

2. J. Parellada, A. Narvaez, M. A. Lopez, E. Dominguez, J. J. Fernandez, V. Pavlov, I. Katakis. Anal. Chim. Acta 362, 47-57 (1998).

3. M. A. Gonzalez-Martinez, R. Puchades, A. Maquieira. TrAC, Trends Anal. Chem. 18, 204-218 (1999).

4. P. D. Patel. TrAC, Trends Anal. Chem. 21, 96-115 (2002).

5. A. F. Collings and F. Caruso. Rep. Prog. Phys. 60, 1397-1145 (1997).

6. D. Meadows. Adv. Drug Delivery Rev. 21, 179-189 (1996).

7. A. P. F. Turner. Science 5495, 1315-1317 (2000).

8. J. Wang, G. Rivas, X. Cai, E. Palecek, P. Nielsen, H. Shiraishi, N. Dontha, D. Luo, C. Parrado, M. Chicharro. Anal. Chim. Acta 347, 1-8 (1997).

9. M. Castillo, M. C. Alonso, J. Riu, M. Reinke, G. Kloter, H. Dizer, B. Fischer, P. D. Hansen, D. Barcelo. Anal. Chim. Acta 426, 265-277 (2001).

10. M. R. Evans, G. M. Jordison, D. M. Rawson, J. G. Regerson. Pestic. Sci. 54, 447 (1998).

11. M. Farre, O. Pasini, M. Carmen Alonso, M. Castillo, D. Barcelo. Anal. Chim. Acta 426, 155-165 (2001).

12. M. Farre and D. Barcelo. TrAC, Trends Anal. Chem. 22, 299-310 (2003).

13. Environmental Agency UK. Direct Toxicity Assessment, Newsletter, July (1999).

14. E. J. Kim, J. E. Lee, M. B. Gu. Water Sci. Technol. 46, 51-56 (2002).

15. M. B. Gu, E. J. Kim, J. Cho, P. D. Hansen. Environ. Monit. Assess. 70, 71-81 (2001).

16. A. J. Oosterkamp, B. Hock, M. Seifert, H. Irth. TrAC, Trends Anal. Chem. 16, 544-553 (1997).

17. M. Usami, K. Mitsunaga, Y. Ohno. J. Steroid Biochem. Molec. Biol. 81, 47-55 (2002).

18. B. Hock, M. Seifert, K. Kramer. Biosens. Bioelectron. 17, 239-249 (2002).

19. M. Seifert, S. Haindl, B. Hock. Anal. Chim. Acta 386, 191-199 (1999).

20. M. Murata, M. Nakayama, K. H. Yakabe, K. Fukuma, Y. Katayama, M. Maeda. Anal. Sci. 17, 387-390 (2001).

21. M. Zhihong, L. Xiaohui, F. Weiling. Anal. Commun. 36, 281-283 (1999).

22. J.-W. Choi, Y.-K. Kim, I.-H. Lee, J. Min, W. H. Lee. Biosens. Bioelectron. 16, 937-943 (2001).

23. V. G. Andreou and Y. D. Clonis. Biosens. Bioelectron. 17, 61-69 (2002).

24. R. T. Andres and R. Narayanaswamy. Talanta 44, 1335-1352 (1997).

25. H. Schulze, S. Vorlova, F. Villatte, T. T. Bachmann, R. D. Schmid. Biosens. Bioelectron. 18, 201-209 (2003).

26. A. Mulchandani, W. Chen, P. Mulchandani, J. Wang, K. R. Rogers. Biosens. Bioelectron. 16, 225-230 (2001).

27. M. H. Smith and G. A. Rechnitz. Anal. Chem. 65, 380 (1993).

28. F. A. McArdle and K. C. Persaud. Analyst 118, 419 (1993).

29. J. Wang and L. Chen. Anal. Chem. 67, 3824-3827 (1995).

30. W. R. Everett and G. A. Rechnitz. Anal. Chem. 70, 807-810 (1998).

31. T. Noguer and J.-L. Marty. Anal. Chim. Acta 347, 63-69 (1997).

32. M. T. Giardi, M. Koblizek, J. Masojidek. Biosens. Bioelectron. 16, 1027-1033 (2001). 
33. C. Vedrine, J.-C. Leclerc, C. Durrieu, C. Tran-Minh. Biosens. Bioelectron. 18, 457-453 (2003).

34. M. Koblizek, J. Maly, J. Masojidek, J. Komenda, T. Kuera, M. T. Giardi, A. K. Mattoo, R. Pilloton. Biotechnol. Bioeng. 78, 110-116 (2002).

35. M. Wilmer, D. Trau, R. Renneberg, F. Spener. Anal. Lett. 30, 515-525 (1997).

36. E. F. Schipper, A. J. H. Bergevoet, R. P. H. Kooyman, J. Greve. Anal. Chim. Acta 341, 171-176 (1997).

37. E. F. Schipper, S. Rauchalles, R. P. H. Kooyman, B. Hock, J. Greve. Anal. Chem. 70, 1192-1197 (1998).

38. K. E. Brummel, J. Wright, M. E. Eldefrawi. J. Agr. Food Chem. 45, 3292-3298 (1997).

39. E. Mallat, C. Barzen, R. Abuknesha, G. Gauglitz, D. Barcelo. Anal. Chim. Acta 427, 165-171 (2001).

40. E. Mallat, C. Barzen, R. Abuknesha, G. Gauglitz, D. Barcelo. Anal. Chim. Acta 426, 209-216 (2001).

41. E. Mallat, C. Barzen, A. Klotz, A. Brecht, G. Gauglitz, D. Barcelo. Environ. Sci. Technol. 33, 965-971 (1999).

42. C. Mouvet, R. D. Harris, C. Maciag, B. J. Luff, J. S. Wilkinson, J. Piehler, A. Brecht, G. Gauglitz, R. Abuknesha, G. Ismail. Anal. Chim. Acta 338, 109-117 (1997).

43. M. A. Gonzalez-Martinez, R. Puchades, A. Maquieira. Anal. Chem. 73, 4326-4332 (2001).

44. J. Peñalva, M.-A. Gonzalez-Martinez, R. Puchades, A. Maquieira, M.-P. Marco, D. Barceló. Anal. Chim. Acta 387, 227-233 (1998).

45. M. Minunni, P. Skladal, M. Mascini. Life Chem. Rep 11, 391-8 (1994).

46. K. Yokoyama, K. Ikebukuro, E. Tamiya, I. Karube, N. Ichiki, Y. Arikawa. Anal. Chim. Acta 304, 139-45 (1995).

47. M. Minunni, P. Skladal, M. Mascini. Anal. Lett. 27, 1475-87 (1994).

48. J. Ngeh-Ngwainbi, P. H. Foley, S. S. Kuan, G. G. Guilbault. J. Am. Chem. Soc. 108, 5444-5447 (1986).

49. J. Horacek and P. Skladal. Biosens. Bioelectron. 12, v-vi (1997).

50. I. G. Lange, A. Daxenberger, B. Schiffer, H. Witters, D. Ibarreta, H. H. D. Meyer. Anal. Chim. Acta 473, 27-37 (2002).

51. D. G. J. Larsson, M. Adolfsson-Erici, J. Parkkonen, M. Pettersson, A. H. Berg, P.-E. Olsson, L. Forlin. Aquat. Toxicol. 45, 91-97 (1999).

52. T. A. Ternes, P. Kreckel, J. Mueller. Sci. Total Environ. 225, 91-99 (1999).

53. A. C. Belfroid, A. Van der Horst, A. D. Vethaak, A. J. Schafer, G. B. J. Rijs, J. Wegener, W. P. Cofino. Sci. Total Environ. 225, 101-108 (1999).

54. Environmental Issues Series, Consultative Report, Environment Agency (1998).

55. P.-D. Hansen, H. Dizer, B. Hock, A. Marx, J. Sherry, M. McMaster, C. Blaise. TrAC, Trends Anal. Chem. 17, 448-451 (1998).

56. C. E. Purdom, P. A. Hardiman, V. J. Bye, N. C. Eno, C. R. Tyler, J. P. Sumpter. Chem. Ecol. 8, 275-285 (1994).

57. S. Rodriguez-Mozaz, S. Reder, M. Lopez de Alda, G. Gauglitz, D. Barceló. Biosens. Bioelectron. 19, 633-640 (2004).

58. A. Boenke. Anal. Chim. Acta 473, 83-87 (2002).

59. G. Marrazza, I. Chianella, M. Mascini. Anal. Chim. Acta 387, 297-307 (1999).

60. C. Q. Zhao, N. A. Anis, K. R. Rogers, R. H. Kline, J. Wright, A. T. Eldefrawi, M. E. Eldefrawi. J. Agric. Food. Chem. 2308-2315 (1995).

61. M. Shimomura, Y. Nomura, W. Zhang, M. Sakino, K.-H. Lee, K. Ikebukuro, I. Karube. Anal. Chim. Acta 434, 223-230 (2001).

62. M. Del Carlo, I. Lionti, M. Taccini, A. Cagnini, M. Mascini. Anal. Chim. Acta 342, 189-197 (1997).

63. N. Lee, C. K. Holtzapple, L. H. Stanker. J. Agric. Food Chem. 46, 3381-3388 (1998). 
64. M. Vanderlaan, L. H. Stanker, B. E. Watkins, P. Petrovic, S. Gorbach. Biotechnol. Adv. 14, 486 (1996).

65. L. H. Stanker, B. Watkins, N. Rogers, M. Vanderlaan. Toxicology 45, 229-243 (1987).

66. P. Pasini, G. Gentlilomi, M. Baraldini, M. Musiani, A. Roda. $12^{\text {th }}$ International Symposium on Bioluminescence and Chemiluminescence (2002).

67. A. Degiuli and L. J. Blum. J. Med. Biochem. 4, 32-42 (2000).

68. J. Angerer, T. Goen, G. Lehnert. Organohalogen Compd. 14, 163-167 (1993).

69. G. Palmer, R. McFadzean, K. Killham, A. Sinclair, G. I. Paton. Chemosphere 36, 2683-2697 (1998).

70. R. Badia and M. E. Diaz Garcia. Anal. Chim. Acta 371, 73-80 (1998).

71. A. N. Reshetilov, I. N. Semenchuk, P. V. Iliasov, L. A. Taranova. Anal. Chim. Acta 347, 19-26 (1997).

72. L. Taranova, I. Semenchuk, T. Manolov, P. Iliasov, A. Reshetilov. Biosens. Bioelectron. 17, 635-640 (2002).

73. J. Waters and T. C. J. Feijtel. Chemosphere 30, 1939-1956 (1995).

74. Y. Nomura, K. Ikebukuro, K. Yokoyama, T. Takeuchi, Y. Arikawa, S. Ohno, I. Karube. Biosens. Bioelectron. 13, 1047-1053 (1998).

75. A. Rose, C. Nistor, J. Emneus, D. Pfeiffer, U. Wollenberger. Biosens. Bioelectron. 17, 1033-1043 (2002).

76. L. Stiner and L. J. Halverson. Appl. Environ. Microbiol. 68, 1962-1971 (2002).

77. P. Sticher, M. C. Jaspers, K. Stemmler, H. Harms, A. J. Zehnder, J. R. van der Meer. Appl. Environ. Microbiol. 63, 4053-4060 (1997).

78. A. Koenig, C. Zaborosch, F. Spener. In Field Screening Europe, J. Gottlieb, H. Hotzl, K. Huck, R. Niessner (Eds.), pp. 203-206, Kluwer Academic, Dordrecht (1997).

79. J. P. Alarie, J. R. Bowyer, M. J. Sepaniak, A. M. Hoyt, T. Vo-dinh. Anal. Chim. Acta 236, 237-244 (1990).

80. I. Coille, S. Reder, S. Bucher, G. Gauglitz. Biomol. Eng. 18, 273-280 (2002).

81. S. J. Setford, R. M. Van Es, Y. J. Blankwater, S. Kroger. Anal. Chim. Acta 398, 13-22 (1999).

82. A. Ahmad, A. Ramakrishnan, M. A. McLean, D. Li, M. T. Rock, A. Karim, A. P. Breau. 300, 177-184 (2002).

83. A. Akkoyun, V. F. Kohen, U. Bilitewski. Sens. Actuators, B 70, 12-18 (2000).

84. L. H. Hansen and S. J. Sorensen. FEMS Microbiol. Lett. 190, 273-278 (2000).

85. S. Subrahmanyam, S. A. Piletsky, A. P. F. Turner. Anal. Chem. 74, 3942-3951 (2002).

86. S. Ramanathan, M. Ensor, S. Daunert. Trends Biotechnol. 15, 500-506 (1997).

87. G. G. Guilbault, D. E. T. Sibley, R. M. Carter, G. J. Lubrano. NATO ASI Ser, Ser. E 252, 377-385 (1993).

88. R. M. Carter, G. J. Lubrano, G. G. Guilbault. Life Chem. Rep. 11, 271-277 (1994).

89. J. B. Delehanty and F. S. Ligler. Anal. Chem. 74, 5681-5687 (2002).

90. G. Palleschi, D. Compagnone, D. Moscone. VTT Symp. 177, 141-160 (1997).

91. C. Tran Minh and P. C. Pandey. Bull. Electrochem. 8, 199-204 (1992).

92. A. A. Boiarski, J. R. Busch, R. S. Brody, R. W. Ridgway, W. P. Altman, C. Golden. Proc. SPIEInt. Soc. Opt. Eng. 2686, 45-52 (1996).

93. C. D. Feng, T. E. Nelson, S. Hardman, P. J. Hesketh, G. J. Maclay, S. M. Gendel, J. R. Stetter. In The $8^{\text {th }}$ International Conference on Solid-State Sensors and Actuators, and Eurosensors IX, pp. 538-541, Stockholm (1995).

94. P. Kumar, J. T. Colston, J. P. Chambers, E. D. Rael, J. J. Valdes. Biosens. Bioelectron. 9, 57-63 (1994).

95. R. A. Ogert, J. E. Brown, B. R. Singh, L. C. Shriver-Lake, F. S. Ligler. Anal. Biochem. 205, 306-312 (1992). 
96. R. S. Marks, Z. M. Hale, M. M. Levine, C. R. Lowe, F. P. Payne. Proc. SPIE-Int. Soc. Opt. Eng. 2131, 495-503 (1994).

97. L. A. Tempelman, K. D. King, G. P. Anderson, F. S. Ligler. Anal. Biochem. 233, 50-57 (1996).

98. E. C. Alocilja and S. M. Radke. Biosens. Bioelectron. 18, 841-846 (2003).

99. A. M. Nasser and S. D. Oman. Water Res. 33, 1748-1752 (1999).

100. S. Toze. Water Res. 33, 3545-3556 (1999).

101. A. Pianetti, W. Baffone, F. Bruscolini, E. Barbieri, M. R. Biffi, L. Salvaggio, A. Albano. Water Res. 32, 1515-1521 (1998).

102. N. Contreras-Coll, F. Lucena, K. Mooijman, A. Havelaar, V. Pierzo, M. Boque, A. Gawler, C. Holler, M. Lambiri, G. Mirolo. Water Res. 36, 4963-4974 (2002).

103. D. Ivnitski, I. Abdel-Hamid, P. Atanasov, E. Wilkins. Biosens. Bioelectron. 14, 599-624 (1999).

104. C. Ercole, M. D. Gallo, M. Pantalone, S. Santucci, L. Mosiello, C. Laconi, A. Lepidi. Sens. Actuators B 83, 48-52 (2002).

105. S. S. Iqbal, M. W. Mayo, J. G. Bruno, B. V. Bronk, C. A. Batt, J. P. Chambers. Biosens. Bioelectron. 15, 549-578 (2000).

106. V. Koubova, E. Brynda, L. Karasova, J. Skvor, J. Homola, J. Dostalek, P. Tobiska, J. Rosicky. Sens. Actuators B 74, 100-105 (2001).

107. S. T. Pathirana, J. Barbaree, B. A. Chin, M. G. Hartell, W. C. Neely, V. Vodyanoy. Biosens. Bioelectron. 15, 135-141 (2000).

108. S. Tombelli, M. Mascini, C. Sacco, A. P. F. Turner. Anal. Chim. Acta 418, 1-9 (2000).

109. Y. Hasebe, K. Yokobori, K. Fukasawa, T. Kogure, S. Uchiyama. Anal. Chim. Acta 357, 51-54 (1997).

110. I. Benhar, I. Eshkenazi, T. Neufeld, J. Opatowsky, S. Shaky, J. Rishpon. Talanta 55, 899-907 (2001).

111. E. R. Goldman, M. P. Pazirandeh, J. M. Mauro, K. D. King, J. C. Frey, G. P. Anderson. J. Molec. Recog. 13, 382-387 (2000).

112. P. Leonard, S. Hearty, J. Brennan, L. Dunne, J. Quinn, T. Chakraborty, R. O'Kennedy. Enzyme Microb. Technol. 32, 3-13 (2003).

113. T. Krawczynski vel Krawczyk, M. Moszczynska, M. Trojanowicz. Biosens. Bioelectron. 15, 681-691 (2000).

114. C. Durrieu and C. Tran-Minh. Ecotoxicol. Environ. Saf. 51, 206-209 (2002).

115. L. D. Rasmussen, S. J. Sorensen, R. R. Turner, T. Barkay. Soil Biol. Biochem. 32, 639-646 (2000).

116. T. D. Yerian, G. D. Christian, J. Ruzicka. Anal. Chim. Acta 204, 7-28 (1988).

117. Y. J. Nam, N. Kim, V. Volotovsky. Sens. Actuators B 42, 233-237 (1997).

118. T. Petanen and M. Romantschuk. Anal. Chim. Acta 456, 55-61 (2002).

119. A. Ivask, M. Virta, A. Kahru. Soil Biol. Biochem. 34, 1439-1447 (2002).

120. C. Ziegler and W. Gopel. Curr. Opin. Chem. Biol. 2, 585-591 (1998).

121. I. Bontidean, J. R. Lloyd, J. L. Hobman, J. R. Wilson, E. Csoregi, B. Mattiasson, N. L. Brown. J. Inorg. Biochem. 79, 225-229 (2000).

122. J. Kulys, I. J. Higgins, J. V. Bannister. Biosens. Bioelectron. 7, 187-191 (1992).

123. U. Wollenberger, F. Schubert, F. W. Scheller. Sens. Actuators, B 7, 412-415 (1992).

124. L. H. Larsen, T. Kjær, N. P. Revsbech. Anal. Chem. 69, 3527-3531 (1997).

125. L. H. Larsen, L. R. Damgaard, T. Kjaer, T. Stenstrom, A. Lynggaard-Jensen, N. P. Revsbech. Water Res. 34, 2463-2468 (2000).

126. A. Abdelghani, N. Jaffrezic-Renault. Sens. Actuators, B 74, 117-123 (2001).

127. J. Liu and B. Mattiasson. Water Res. 36, 3786-3802 (2002).

128. W. Bourgeois, J. E. Burgess, R. M. Stuetz. J. Chem. Technol. Biotechnol. 76, 337-348 (2001).

129. Z. Qian and T. C. Tan. Water Res. 33, 2923-2928 (1999).

130. F. Li and T. C. Tan. Biosens. Bioelectron. 9, 315-324 (1994).

131. G.-J. Chee, Y. Nomura, K. Ikebukuro, I. Karube. Biosens. Bioelectron. 15, 371-376 (2000). 
132. H. J. Purohit. J. Cleaner Prod. 11, 293-301 (2003).

133. H. A. Fishman, D. R. Greenwald, R. N. Zare. Annu. Rev. Biophys. Biomol. Struct. 27, 165-198 (1998).

134. F. Ortega, E. Dominguez, E. Burestedt, J. Emneus, L. Gorton, G. Marko-Vargo. J. Chromatogr. A 675, 65-78 (1994).

135. O. Adeyoju, E. Iwuoha, M. Smyth, D. Leech. Analyst 121, 1885-1889 (1996).

136. S. Kroger, S. Piletsky, A. P. F. Turner. Mar. Pollut. Bull. 45, 24-34 (2002).

137. R. L. Rich and D. G. Myszka. Curr. Opin. Biotechnol. 11, 54-61 (2000).

138. I. Lundstrom and S. Svensson. Curr. Appl. Phys. 2, 17-21 (2002).

139. L. Tiefenauer and R. Ros. Colloids Surf. B: Biointerfaces 23, 95-114 (2002).

140. S. Kossek, C. Padeste, L. X. Tiefenauer, H. Siegenthaler. Biosens. Bioelectron. 13, 31-43 (1998).

141. D. t. i. center.

142. T. H. Wink, S. J. van Zuilen, A. Bult, W. P. van Bennekom. Analyst 122, 43-50 (1997).

143. L. X. Tiefenauer, S. Kossek, C. Padeste, P. Thiebaud. Biosens. Bioelectron. 12, 213-223 (1997).

144. A. J. Haes and R. P. Van Duyne. J. Am. Chem. Soc. 124, 10589-10595 (2002).

145. M. D. Malinsky, K. L. Kelly, G. C. V. D. Schatz, P. Richard. J. Am. Chem. Soc. 123, 1471-1482 (2001).

146. T. A. Taton, G. Lu, C. A. Mirkin. J. Am. Chem. Soc. 123, 5164-5165 (2001).

147. Y. Cao, R. Jin, C. A. Mirkin. J. Am. Chem. Soc. 123, 7961-7962 (2001).

148. A. A. Lazarides, K. Lance Kelly, T. R. Jensen, G. C. Schatz. J. Mol. Struct. 529, 59-63 (2000).

149. K. Ramanathan and B. Danielsson. Biosens. Bioelectron. 16, 417-423 (2001).

150. C. E. H. Berger, T. A. M. Beumer, R. P. H. Kooyman, J. Greve. Anal. Chem. 70, 703706 (1998).

151. C. A. Rowe-Taitt, J. P. Golden, M. J. Feldstein, J. J. Cras, K. E. Hoffman, F. S. Ligler. Biosens. Bioelectron. 14, 785-794 (2000).

152. C. A. Rowe-Taitt, J. W. Hazzard, K. E. Hoffman, J. J. Cras, J. P. Golden, F. S. Ligler. Biosens. Bioelectron. 15, 579-589 (2000).

153. R. M. Wadkins, J. P. Golden, L. M. Pritsiolas, F. S. Ligler. Biosens. Bioelectron. 13, 407-415 (1998).

154. T. T. Bachmann and R. D. Schmid. Anal. Chim. Acta 401, 95-103 (1999).

155. C. Mastichiadis, S. E. Kakabakos, I. Christofidis, M. A. Koupparis, C. Willetts, K. Misiakos. Anal. Chem. 74, 6064-6072 (2002).

156. C. Barzen, A. Brecht, G. Gauglitz. Biosens. Bioelectron. 17, 289-295 (2002).

157. M. Sequeira, M. Bowden, E. Minogue, D. Diamond. Talanta 56, 355-363 (2002).

158. H. Suzuki. Mater. Sci. Eng. C 12, 55-61 (2000).

159. <http://www.cranfield.ac.uk/biotech/chinap.htm>

160. J. Antonio Gabaldon, A. Maquieira, R. Puchades. Crit. Rev. Food. Sci. Nutr. 39, 519-538 (1999).

161. D. R. Thevenot, K. Toth, R. A. Durst, G. S. Wilson. Biosens. Bioelectron. 16, 121-131 (2001).

162. B. Kuswandi, R. Andres, R. Narayanaswamy. Analyst 1469-1491 (2001).

163. A. Keane, P. Phoenix, S. Ghoshal, P. C. K. Lau. J. Microbiol. Meth. 49, 103-119 (2002).

164. L. H. Hansen and S. J. Sorensen. FEMS Microbiol. Lett. 193, 123-127 (2000).

165. C. Nistor, A. Rose, M. Farre, L. Stoica, U. Wollenberger, T. Ruzgas, D. Pfeiffer, D. Barcelo, L. Gorton, J. Emneus. Anal. Chim. Acta 456, 3-17 (2002).

166. D. Frense, A. Muller, D. Beckmann. Sens. Actuators, B 51, 256-260 (1998).

167. S. H. Choi and M. B. Gu. Biosens. Bioelectron. 17, 433-440 (2002).

168. T. C. Tan and C. Wu. Sens. Actuators, B 54, 252-260 (1999).

169. B. Catimel, J. Weinstock, M. Nerrie, T. Domagala, E. C. Nice. J. Chromatogr. A 869, 261-273 (2000).

170. M. Murata, M. Nakayama, H. Irie, K. Yakabe, K. Fukuma, Y. Katayama, M. Maeda. Anal. Sci. 17, 387-390 (2001). 
171. T. Wink, J. de Beer, W. E. Hennink, A. Bult, W. P. van Bennekom. Anal. Chem. 71, 801-805 (1999).

172. K. Kukanskis, J. Elkind, J. Melendez, T. Murphy, G. Miller, H. Garner. Anal. Biochem. 274, 7-17 (1999).

173. A. Giuseppi-Elie, G. Wallace, T. Matsue. In Handbook of Conducting Polymers, T. A. Skotheim, R. L. Elsenbaumer, J. R. Reynolds (Eds.), Marcel Dekker, New York (1998).

174. S. A. Glazier, E. R. Campbell, W. H. Campbell. Anal. Chem. 70, 1511-1515 (1998). 